\title{
Being and Becoming a Teacher in Initial Literacy and Second Language Education for Adults
}

\author{
Helena Colliander
}

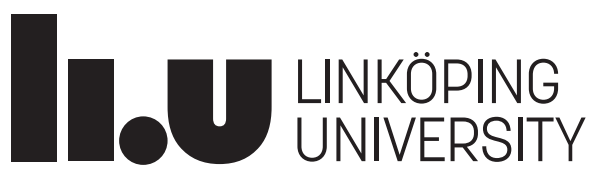

Linköping Studies in Behavioural Science No. 205

Faculty of Educational Sciences

Linköping 2018 
Linköping Studies in Behavioural Science • No. 205

Distributed by:

Department of Behavioural Sciences and Learning

Linköping University

SE-581 83 Linköping

Helena Colliander

Being and Becoming a Teacher in Initial Literacy and Second Language Education

Edition 1:1

ISBN 978-91-7685-304-7

ISSN 1654-2029

(c) Helena Colliander

Department of Behavioural Sciences and Learning, 2018

Cover photo: Susanna Cederquist

Printed by Liu-tryck, Linköping 2018 


\section{Table of Contents}

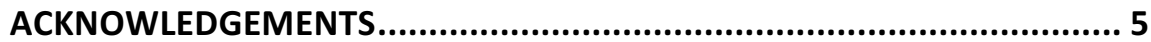

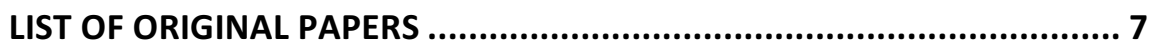

INTRODUCTION

BACKGROUND....................................................................... 9

GENERAL AIM AND RESEARCH QUESTIONS............................................ 13

OUTLINE OF THE THESIS ............................................................ 14

\section{PREVIOUS RESEARCH RELATED TO LESLLA IDENTITY AND LESLLA}

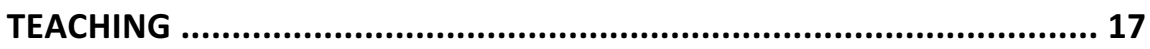

PROFESSIONAL TEACHER IDENTITY FORMATION ........................................ 17

THE PROFILE AND CONDITIONS OF AN ADULT EDUCATOR..............................20

SECOND LANGUAGE TEACHER COMPETENCY ........................................... 22

MOTHER TONGUE TEACHING ............................................................. 24

MOTHER TONGUE TEACHERS AND TEACHERS WITH AN IMMIGRANT

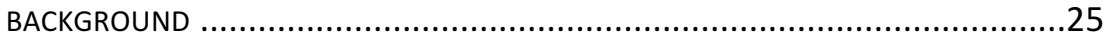

PERSPECTIVES ON INITIAL LITERACY TEACHING .......................................... 27

PERSPECTIVES ON EMERGENT READERS ................................................29

BEING A TEACHER OF LESLLA LEARNERS............................................ 31

IMPLICATIONS FROM PREVIOUS RESEARCH ........................................... 32

THEORETICAL PERSPECTIVES ..................................................... 35

FOUNDATIONS OF SITUATED LEARNING THEORY ..................................... 35

IDENTITY FORMATION IN A COMMUNITY OF PRACTICE .................................. 36

IDENTITY FORMATION IN A LANDSCAPE OF PRACTICES .................................. 38

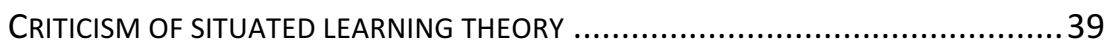

FIELD AND CAPITAL - COMPLEMENTING SITUATED LEARNING WITH BOURDIEUAN CONCEPTS ............................................................................ 41

THEORETICAL IMPLICATIONS FOR THIS STUDY ...................................... 43

LESLLA EDUCATION IN SWEDEN.............................................. 45

THE EDUCATIONAL SYSTEM OF SFI .............................................. 45

THE MISSION OF A LESLLA TEACHER WITHIN SFI .................................47 
METHODOLOGY ....................................................................... 51

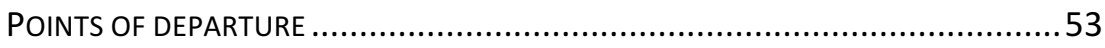

RESEARCH SETTINGS AND PARTICIPANTS ............................................ 53

OBSERVATIONS ................................................................... 55

SEMI-STRUCTURED INTERVIEWS, BEGINNING WITH THE TELLING OF A STORY .......57

Reflections on conditions influencing the interviews...................59

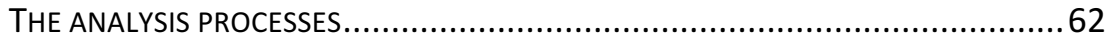

Transcribing interviews and demarcating each study ..................62

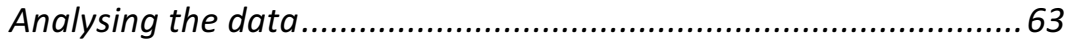

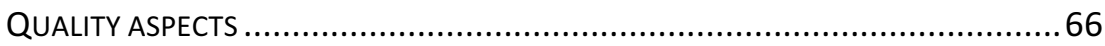

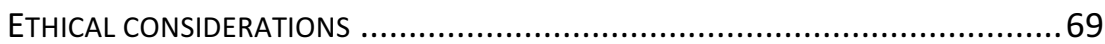

REFLECTIONS ON THE RESEARCH PROCESS ............................................ 71

SUMMARIES OF THE SUBSTUDIES........................................... 74

THE RELATIONSHIPS BETWEEN THE SUBSTUDIES ..................................... 74

ARTICLE I: ACTIONS AND CONCEPTIONS: EXPLORING INITIAL LITERACY TEACHING

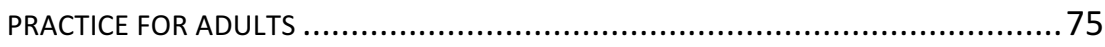

ARTICLE II: THE EXPERIENCED NEWCOMER - THE (TRANS)FORMING OF PROFESSIONAL TEACHER IDENTITY IN A NEW LANDSCAPE OF PRACTICES

ARTICLE III: BUILDING BRIDGES AND STRENGTHENING POSITIONS: EXPLORING THE IDENTITY CONSTRUCTION OF IMMIGRANT BILINGUAL TEACHERS

ARTICLE IV: BEING TRANSFORMED AND TRANSFORMING ONESELF IN A TIME OF CHANGE: A STUDY OF TEACHER IDENTITY IN SECOND LANGUAGE EDUCATION FOR ADULTS

OVERALL FINDINGS OF THE THESIS ................................................. 82

DISCUSSION ......................................................................... 86

CONSTRUCTING IDENTITY IN REGARD TO THE PARTICULAR NATURE OF THE

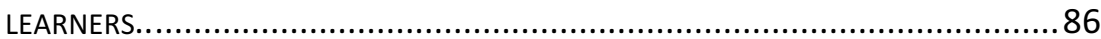

BECOMING A LESLLA TEACHER IS AN ONGOING PROCESS... ......................... 88

... EVOLVING IN MULTIPLE COMMUNITIES............................................ 89

...IN REGARD TO POWER RELATIONS ................................................... 90

SYNTHESISING REMARKS .................................................................. 93

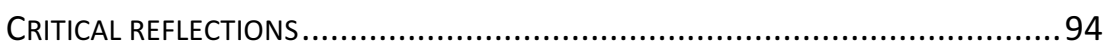

IMPLICATIONS AND FUTURE RESEARCH ............................................. 95 


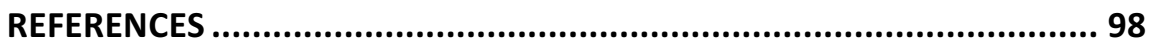

APPENDIX A: OBSERVATION GUIDE FOR THE TEACHING PRACTICE ....113 APPENDIX B: INTERVIEW GUIDE - FOR THE TEACHERS.......................114 APPENDIX C: INTERVIEW GUIDE - FOR A COMPLETING INTERVIEW LATER IN THE PROJECT ...............................................................116

APPENDIX D: INTERVIEW GUIDE WITH THE PRINCIPALS......................118 APPENDIX E: TABLE 2: PARTICIPANTS 119

\section{LIST OF TABLES}

Table 1: The studies and their overall methodological features...52 



\section{Acknowledgements}

This thesis is about being and becoming a teacher in a certain landscape of teaching practices. The participants in the study have learned from their trajectories in various communities of this landscape. But they are not the only ones who have developed their professional identity: a similar process have been an integral part of my personal development while working with the project. I, too, have walked along a pathway of professional identity, in my case, towards the centre of different academic communities.

Writing a thesis is something you do on your own, but a number of people are involved in it. For my part, I have had the privilege to learn from many others along the way. Two key people are my supervisors Per Andersson and Song Ee Ahn. Thank you for many constructive ideas of how to proceed with the manuscripts, for trusting that the process would run its course (especially when I had doubts about it myself), and for practical and emotional support. I have learnt a lot from you!

Two people were $\mathrm{PhD}$ students in the same cohort, and thus shared the whole journey with me. Thank you Sofia Österborg Wiklund and Lina Rahm for your encouragement and refreshing perspectives. Thanks Diana Holmqvist for paying attention to many crucial details during the writing of the thesis. I'm also grateful to all other colleagues at the Division of Education and Adult Learning at Linköping University, for inspiration, kind words and constructive feedback.

Moreover, I would like to thank Katarina Eriksson Barajas for many valuable comments towards the end of the process, Sofia Nyström for input on the theory part, and Charlotta Plejert and Marie Carlson for the comments in connection with the $60 \%$ and $90 \%$ seminars.

I am grateful to the LESLLA teachers who have participated in this study. You have generously shared your experiences and allowed me to study how you work. Likewise, I appreciate the principals who gave me the background to their schools and their perspectives on LESLLA teaching. I am grateful to Qarin Franker and Margareta Mörling, who helped me to gain access to the field. 
In addition, my gratitude goes to Dessu Wirtu, Abdel Aziz and the other colleagues at the College of Education and Behavioural Studies at Addis Abeba University. You gave me a warm welcome as a guest lecturer and visiting researcher. The visit there gave me both new perspectives and energy to carry on with the thesis. Also, thank you Per-Olof Hansson, who facilitated the arrangements for the visit.

There are many people outside of academia who have been part of this process. Thank you Susanna Cederquist, Lisa Cederquist, Sara Almer, Greta Mörling, and others for travelling with me during the holidays. It gave me well-needed breaks. Thank you, Lisa Davidson for your input on the cover page as well as for stimulating conversations, and thanks to all my friends for great fun in company, for encouragement, and for reminding me that a thesis is, after all, just a thesis.

I'm grateful to my brother Rickard, and his family, Karin, Gustav and Karl, not least for hosting me for a couple of writing weeks in your home. The first visit became a crucial turning point in the process. Finally, my gratitude goes to my mum and dad, Margareta and Roger, and to my sister, Hanna for always being there for me.

Stockholm, March 2018 


\section{List of original papers}

This thesis is based on the following studies:

I Colliander, H., Ahn, S. E. \& Andersson, P., Actions and conceptions: exploring initial literacy teaching practice for adults. Manuscript accepted in Journal of Language, Identity \& Education doi: 10.1080/15348458.2018.1465344

II Colliander, H. (2018). The experienced newcomer - the (trans)forming of professional teacher identity in a new landscape of practices. Manuscript published online in Teaching and Teacher Education, 69(1), 2018, 168-176. doi: 10.1016/j.tate.2017.10.012

III Colliander, H. (2017). Building bridges and strengthening positions: exploring the identity construction of immigrant bilingual teachers. Manuscript published online in International Journal of Bilingual Education and Bilingualism. doi: 10.1080/13670050.2017.1400516

IV Colliander, H. Being transformed and transforming in a time of change: a study of teacher identity in second language education for adults. Manuscript submitted for publication. 



\section{Introduction}

\section{Background}

I was Omaima, a secondary school teacher from Iraq . . . . I came 1993. Then I started to work 2000, almost ten years later ... . Now, I'm a teacher with lots of experience when it comes to initial literacy teaching, when it comes to other cultures, when it comes to the understanding of - and this is the most important - the needs of others. So, this journey - I feel that it's been fantastic.

This thesis is about the professional identity of teachers of Literacy Education and Second Language Learning for Adults (LESLLA) ${ }^{1}$. Throughout the study, this is regarded as a lifelong learning process, which develops in regard to a number of different conditions and in relationships with other people.

With the vast migration that is seen globally today ( United Nations, Department of Economics and Social Affairs, 2017), this type of teaching becomes of great importance, both for individuals and for society in general. One thing that characterizes LESLLA education is initial literacy teaching. The number of adults (over the age of 15), who have not received the opportunity to acquire basic literacy skills is estimated to be 750 million, 2/3 of them being women (UNESCO Institute for Statistics, 2017). The figure is higher in countries where less people have access to basic education, but due to migration, there is an increasing number of illiterate adults in other countries. In Sweden, where this study is located, $8 \%$, i.e. slightly more than 12,000 of the adults enrolled in the Swedish for Immigrants (SFI) courses, had had less than three years of schooling and participated in the initial literacy training

\footnotetext{
${ }^{1}$ The meaning of the LESLLA abbreviation was officially changed during the work of this thesis. Thus, LESLLA in the first article is an abbreviation for Low Educated Second Language and Literacy Acquisition.
} 
courses during 2016 (Swedish National Agency for Education, 2017a).

To be orally literate, rather than print literate, in many societies implies alienation. In a text-based culture, where there is a perpetual flow of information, literacy is a condition for obtaining information as well as classifying and examining it. Literacy is a means of communication, necessary for practically all types of employment, and for activities connected to societal orientation; for example for paying bills and for buying items or reporting problems online. By becoming print literate, individuals can also gain a new way of understanding the world and develop their thinking, and these are processes that in turn can generate a greater selfconfidence and self-esteem (Bhola, 2008, p. 28). To some extent, such personal development can be related to illiteracy amongst adults being generally viewed as a deficiency (see Crowther, Hamilton, \& Tett, 2001, p. 2).

It is often a challenge for an adult learner to acquire literacy (with everything it implies), and even if many conditions influence the learning process, the teacher plays a key role in supporting this process. The view teachers have of teaching and learning will naturally reflect how they design the teaching, and the way of teaching will have an impact on the student's learning (Trigwell, Prosser, \& Waterhouse, 1999). In addition, LESLLA teachers also play a central part in supporting the learners when they develop a second language and establish themselves in a new society. The term 'LESLLA learners' has the advantage that it reflects the students as learners of initial literacy and second language, at the same time as it indirectly implies that they are less used to schooling. However, in spite of these intertwined challenges, LESLLA teachers have been little researched.

Moreover, by being adult educators, the LESLLA teachers' status is often low. In many European countries, the professional profile of adult educators has not been identified, regulated or acknowledged (Milana et al., 2010, p. 61). It is common throughout the world that adult educators do not have adequate education (UNESCO, n.d.). When it comes to LESLLA teachers in particular, many of them have not received sufficient training for this specific type of teaching, even if a number of them are well educated and have degrees in education (Vinogradov \& Liden, 2009; Erguig, 
2012; Perry \& Hart, 2012, p. 111). The LESLLA teachers in Sweden work in the educational system of SFI. Figures from the school year 2016-2017 show that whereas nearly $70 \%$ of the teachers in SFI there had a degree in teaching, only $36.5 \%$ were authorized to teach within this system (Swedish National Agency for Education, 2017b). For the teachers working in non municipal SFI settings, the percentage of teachers with a degree in education was as low as $64 \%$ (Swedish National Agency for Education, 2017c).

Due to a shortage of SFI teachers in general, formal qualification is not always a criterion to teach (National Centre for Swedish as a Second Language, 2012) and until recently some requirements for SFI teachers have not been formally stated. Still, a research review from the Swedish Research Council points out that:

major flaws in the formal qualification of the teachers pose a serious threat to the equivalence of education itself, as well as for the assessment of the students' language skills, which may be crucial for the individual's future opportunities. The need for professionalization of second language teaching for adults, in terms of an adequate formal teacher training, and a solid research basis for teachers to make professional choices and considerations and perform their tasks in accordance with the intentions of the governing documents cannot be stressed enough (Lindberg, \& Sandwall, 2012, p. 476, my translation).

The quotation reflects the needs of both education for, and research relating to, SFI teachers. Moreover, research on LESLLA teaching and learning has led to criticism: it has been claimed, for example, that the teachers alienate the learners and do not acknowledge their experiences and cultures (Lundgren, 2005, pp. 180-182; Franker, 2007, pp. 115-116). This can be prevented if LESLLA teachers are given the opportunity to develop greater expertise (Franker, 2007, pp. 115-116).

The status of LESLLA teachers is low not just because of a lack of adequate education. There is also the matter of employment conditions. Many educators of adult literacy in the world are 
working as volunteers and/or part-time workers (see Sun, 2010, p. 145; Erguig, 2012; Perry \& Hart, 2012, p. 111). In addition, the discourse of professionalisation of teachers has changed the structure of their working tasks and forced them to make reprioritizations. Among other things, they must concentrate on measurable objectives and reserve more time for administration (Evetts, 2012). Research shows how the restructuring of adult education in a Swedish municipality led to negative effects for the working conditions within SFI, and a decrease in the ability of the teachers' union to influence the education. In other words, the teachers have lost a certain amount of professional freedom and have been forced to adapt to the market, in order to continue to work within the adult education sector (Beach, 2004, pp. 175-176; Beach \& Carlson, 2004, p. 687). The teachers' insecure position in the labour market and the increased financial control can result in a conflict of interest in which they are squeezed between the students' needs and the goals of the syllabus on the one hand, and the providers' goal of obtaining statistics that show that their education leads to job positions, on the other hand (Sandwall, 2010, p. 546).

Figures from 2017 show that $31 \%$ of SFI teachers did not have a permanent position (Swedish National Agency for Education, 2017c). This is more common in private SFI education, where the contracts with the municipality are often written for a period of two years (National Centre for Swedish as a Second Language, 2008).

Attempts to increase the professionality of the teachers, especially through education, have been made. To become authorized, SFI teachers are required to have a formal teaching degree for primary or secondary school, and they should have 30 credits in Swedish as a Second Language. However, the subject qualification is regarded to be far too low, especially when it comes to such a challenging work as initial literacy teaching (National Centre for Swedish as a Second Language, 2012). As a result of this requirement employers who former explicitly required SFI teachers to have at least 60 credits in Swedish as a Second Language, nowadays only require 30 credits. This means that even if teachers are authorized, it is not certain that all teachers have sufficient subject-specific expertise. In response, some municipalities and 
other educational organizers have chosen to require 60 credits as a condition for permanent employment.

Even if SFI teachers form the backbone of SFI teaching, the schools have the opportunity to employ mother tongue teachers too. Both groups are to teach Swedish, but the mother tongue teachers are to use a students' mother tongue as a tool for students to learn literacy and Swedish. The number of mother tongue teachers is significantly smaller, but they, too, are included in this study, since LESLLA teachers are defined by the learners they teach rather than their type of employment. If there is a lack of authorized mother tongue teachers, the school can offer a permanent position also to applicants who are not formally qualified (Swedish National Agency for Education, 2015). This implies that they, as a group, have limited formal expertise as well.

Another attempt to improve the quality and to coordinate the LESLLA teachers' expertise can be seen in the first common Nordic description of the competencies of a LESLLA teacher. This description has been published by the Nordic network for adult learning with the aim of mapping "the competencies required of a professional teacher of initial and functional literacies to adults whose mother tongue is not a Nordic language" (Alfarådet, 2013). The description was preceded by an enquiry that aimed to map LESLLA teaching in the Nordic countries (National Centre for SFI and Swedish as a Second Language, 2007).

When considering these efforts to achieve professionalization, it is essential to consider the professional identity of LESLLA teachers, which is formed in regard to the efforts, among other things. Given the ascribed importance of autonomous and competent LESLLA teachers, this thesis contributes perspectives on how teachers act, learn and understand themselves in the encounter with the work-related communities they are a part of.

\section{General aim and research questions}

As has been stated in the previous section, many of the teachers lack an education that focuses on SFI and LESLLA teaching and learning. Instead, their professional LESLLA teacher identity is developed in work practices. The theory of situated learning, the 
theoretical perspective on which this study is mainly based, suggests that teachers, like other workers, belong to many different and overlapping professional practices (Wenger-Trayner \& Wenger-Trayner, 2015, p. 15).

The overall aim of the thesis is to explore what being and becoming a teacher of LESLLA learners means. The study seeks to depict how the professional identity of LESLLA teachers can be understood from their memberships of different communities of practice. The research questions are:

- What are the significant teaching actions of LESLLA teachers, and what are the conceptions behind these actions? (I)

- How is a professional teacher identity formed in the encounter with LESLLA teaching practice? (II)

- How do bilingual immigrant teachers in the field of LESLLA teaching construct a professional identity? (III)

- What do changes in the overall field of second language education for adults mean for LESLLA teachers' professional identity? (IV)

As the numbers after each research question indicate, each question is addressed in particular in one of the four articles. The exploration of these questions will improve our possibilities to understand and support the teachers' development. Moreover, the results are not just of interest for teachers of LESLLA, but can also inform other types of adult educator, especially within the field of adult education and second language teaching and learning.

\section{Outline of the thesis}

The intention of this first chapter has been to give a background to the study and to introduce its purpose. In chapter 2, I provide an overview of previous research when it comes to areas related to LESLLA teacher identity. In chapter 3, I introduce the study's conceptual framework - the situated learning theory and some concepts of Bourdieu that are used as complementary thinking 
tools. In the fourth chapter, I then give the context of the study by describing several aspects of SFI and LESLLA education in Sweden. This is followed by the methodology chapter (5), in which I give an account of how the study has been carried out in terms of design and analysis. I also reflect in chapter 5 about the aspects of quality, ethical considerations and the research process. In chapter 6, I show how the four substudies of this thesis relate to each other. I provide a summary of each of them and present the overall findings of the thesis. The final chapter (7) consists of a discussion of the overall results, and a critical reflection of the thesis. I also say something about its implications and give suggestions for future research. Finally, the observation guide, the interview guides, and a table of all research participants are presented in the appendices. These are followed by the four articles in full. 



\section{Previous research related to LESLLA identity and LESLLA teaching}

Identity is a huge research area. For example, it can be treated either as a general phenomenon, or more specifically as work identity or professional identity. In this study I have narrowed the scope down to professional teacher identity. In this chapter, I begin with a brief overview of research that says something about professional teacher identity as an overall phenomenon. Then, in the following sections, I elaborate on major themes concerning teacher identity that have been identified in studies dealing with different aspects of being a LESLLA teacher. These sections deal with research on adult educators, second language teachers, mother tongue teaching, mother tongue teachers, and teachers with an immigrant background. I also discuss research on initial literacy teaching, emergent readers and LESLLA teachers in particular. Finally, I discuss the implications of previous research for this study.

\section{Professional teacher identity formation}

Teachers' professional identity is a distinct field of research. This identity has been interpreted from a variety of perspectives. According to Sachs (2005) being a teacher is not just about developing skills. It contains also "an understanding of what it means to be a teacher in one's own eyes and in the eyes of others" (p. 8). Furthermore, she states that being a teacher is about one's actions and how one identifies with different groups. This implies that many issues contribute to the teacher identity.

'Learning how to teach' is something that springs from teachers' own experiences of being learners in school contexts and participants in teacher programs (Freeman \& Johnson, 1998, p. 401). The connection to one's experience as a student is almost unique to the teacher profession. A positive experience of one's own teacher or of a pedagogical approach influences teachers' beliefs in their own current teaching and learning practices. Likewise, the outlook of the learner resembles the conception they 
have of themselves as students. This affects how they describe the learners and what they expect from them (Taylor, 2003, p. 72).

Another theme is that teacher identity is dynamic, and develops over time as experiences are interpreted and re-interpreted (Beijaard, Meijer \& Verloop, 2004, pp. 122-123; Beauchamp \& Thomas, 2009, p. 177). Teachers with more experience of teaching tend to portray themselves in terms of the relationships with students and the educational context, whereas less-experienced teachers tend to focus on the subject and methods of teaching (Andersson, Köpsén, Larson \& Milana, 2012, p. 113).

Some periods of a teacher's career have particular importance for the identity formation, and this is also a part of the dynamic aspect of teacher identity. One easily identified period is when a teacher is new in the profession (Avalos, 2011, p. 11; Kanno \& Stuart, 2011). Liu and Fisher (2006) find that cognitive and emotional factors, such as reflections and relationships, help novice teachers to develop a professional identity, as do social factors, such as academic, institutional, and curriculum conditions. Moreover, by applying the perspective of situated learning, Kanno and Stuart (2011) illustrate that moving from being a graduate student to a professional teacher is a slow process in which the novice teachers identify and develop the features of teaching that are important for them. As the teacher identity developed, they acquired more authority.

However, the development of professional identity is not limited to novice teachers. Teachers who have participated for a long time in a teaching community can still meet challenges from outside that change work practices within and thus imply learning (Hodkinson \& Hodkinson, 2003, p. 17). This may be the case in times of reform. During such periods, teachers must negotiate what the reform means for themselves and take different stances towards it. Whereas some teachers resist a reform, others accept it or take an ambivalent position. The response depends on their previous work experiences and future prospects (Vähäsantanen \& Eteläpelto, 2009). Sometimes, a reform can clash with the teachers' sense of identity, since this is intertwined with the aim of schooling and how one is to be a teacher (Lasky, 2005). Buchanan (2015, p. 714) sees how teachers' ability to be the teachers they wish to be is crucial in how they negotiate reform. The teachers use their professional 
identities, mainly formed by previous work experiences, to interpret the new norms. At the same time, however, the actions the teachers take in turn influence their identities (Buchanan, 2015, p. 714). Thus, the shift in identity depends both on teachers' actions and self-concept, and this links the teacher identity to agency.

Teacher agency is regarded as a striving for learning in compliance with one's objectives (Beijaard, Meijer \& Verloop, 2004, p. 123). It is summarized by following words: "professionals such as teachers have the power to act, to affect matters, to make decisions and choices, and take stances, for example in relation to their work and professional identities" (Vähäsantanen, 2015, p. 2). Teachers negotiate their professional identities depending on a number of things, such as their workload, performance, and concerns about their own well-being and that of their students (Vähäsantanen \& Billett, 2008). Their agency springs both from individual resources in terms of such matters as professional experiences, expertise and interests, and social resources such as the management culture of the institutions, which impacts the curriculum and work content (Vähäsantanen 2015, p. 7). Similarly, teacher identity is a matter of both the individual and the context they work in. The context provides a frame but the teachers negotiate this (Beijaard, Meijer \& Verloop, 2004, p. 122). However, Rappel (2015, p. 324) points out that teachers, to connect the agenda and the objectives of the workplace with their individual backgrounds, depend on the security and stability of their workplaces. They need to trust others and believe in themselves in order to grow professionally.

The social nature of teachers' professional identity is visible not just in how teachers develop through their interactions in their workplaces and other teacher and learning communities. The macro conditions, such as the nature of the educational system and the policy directives that apply are also central (see Avalos, 2011, p. 12). As discussed above, reforms have a huge impact on teachers' identity. Another example of the social aspect of teacher identity is the subject of teaching. Hökkä, Rasku-Puttonen and Eteläpelto (2008) highlight how a group of teacher educators strongly identified with their subject matter groups. This was because there was little collaboration between them and other teacher groups. Additionally, Hodkinson and Hodkinson (2004, p. 30) show how 
practices in different subject departments contributed to varieties in how the teachers learned. The nature of the social relations within them had for examples implications for if the learning was collaborative or individualistic.

Another theme linked to teacher identity is the teachers' relationships with their students. Even if not focusing on that particular relationship, many studies indirectly touch upon this matter. Buchanan (2015), for example, shows how concerns for their students guide the teachers' response to a reform, while Tsui (2007, pp. 670-671) describes how a teacher is caught between the responsibility he or she feels for the students and the institutional expectations of how to teach. Also, as previously stated, Andersson et al. (2012, p. 115) have shown that relationships with the students are more important for experienced teachers.

The many professional contexts and communities of which the teachers are a part means that teacher identity consists of many subidentities. Some of these are considered to be core identities, whereas others are peripheral. The subidentities need to be balanced against each other to avoid internal conflict, but to change or lose one of the core identities is very difficult (Beijaard, Meijer, \& Verloop, 2004, p. 122). This difficulty is exemplified in studies of Liu and $\mathrm{Xu}(2011 ; 2013)$, in which a teacher, due to a shift from traditional to liberal pedagogies, came into conflict with her/himself when negotiating the new order. Since s/he could not align to these required changes, s/he came to choose an outbound trajectory from the community of teachers s/he belonged to.

From this review, it has become clear that many issues contribute to teacher identity. To make it even more complex, as well as to be more specific, I will continue to elaborate on what research says about teacher identity in regard to the different educational fields to which a LESLLA teacher belongs. One of these is adult education.

\section{The profile and conditions of an adult educator}

Adult education is a wide field, which includes for example second language education, complementary education, and vocational 
training. The highly diverse nature of the field has led to a debate about whether it is possible to define a certain professionalism for adult educators, and if so, how it will be framed (Nicoll \& Edwards, 2012 , p. 233). There are varieties in teaching within the field since different educational systems have different purposes, and since the educators have a high degree of freedom from governmental control (Larsson, 2006, p. 12-13). Adult education may be formal and/or non-formal, and the requirements for teachers of the different types differ (see Milana, 2010). Furthermore, not all countries stipulate formal qualification standards of the teachers' qualifications.

However, many studies in Europe have highlighted the adult educators' education and learning and/or their profile and competences (see e.g. Lattke \& Jutte, 2015). Some claim that there are core competencies that are valid regardless of the setting. For example, Wahlgren (2016, p. 351) argues that there are four general competencies: the ability to communicate the subject with adequate teaching methods in an inspiring and understandable way, the ability to include in teaching what the learners already have learned, the ability to create a beneficial learning environment, and the ability to reflect on ones' own performance for the sake of improving it. Another study focusing on 'generic teacher skills' in adult and community training highlights five principal elements. Apart from self-reflection for learning, the elements are the willingness to take risks, the awareness of power relations, the ability to be patient and trust the learning process, and engagement with the learners (Sanguinetti, Waterhouse \& Maunders, 2005).

The studies made on the education, profiles and competency of adult educators can be understood in the light of professionalization of this group (Wahlgren, 2016, p. 351). Due to a societal transformation in which innovations and knowledge are becoming increasingly valued, the adult education sector in the EU has expanded, and there are demands that the education should meet the expectations of the labour market. Furthermore, the current focus on lifelong learning implies that formal, non-formal, and informal opportunities for learning must be strengthened (Sava \& Lupou, 2009, p. 2228). In this context, Nicoll and Edwards (2012) illustrate how three common discourses of the adult educator, namely the teacher as a technical expert, a competent worker and a reflective practioner, are used to activate particular types of 
professional identity and practice. Moreover, Nicoll and Edwards state that the teacher must negotiate her/his own commitment and dispositions in connection with work practices, and the standardised competency requirements according to which $\mathrm{s} / \mathrm{he}$ is measured. The professionalisation of adult educators is ambiguous. On the one hand, the social recognition of them as professionals has increased, as an understanding of the complexity of their work, while on the other hand, the professionalization efforts imply that the teachers' work is to be measured in regard to ambitious policy targets, and that attention is paid to competitiveness rather than to humanistic values (Guimãraes, 2009, p. 218).

\section{Second language teacher competency}

The LESLLA teacher is characterised not only by being a teacher in adult education. Since the subject of teaching also plays a crucial part for teacher identity, this section highlights what research says about second language teachers. Second language teachers within adult education also face the issues of professionalization and reforms intended to make teaching and learning more efficient (Rappel 2015, pp. 320-322). For example, Sandwall (2013, p. 198) illustrates how SFI teachers are trapped between curriculum regulations on language teaching and the municipalities' demand for teaching that concentrates on workplace learning. There seems to be three common areas of second language teacher competency; language teaching knowledge and skills, knowledge of the refugee and immigrant experience, and attitudes towards learners ${ }^{2}$.

Research on second language teachers shows that a uniform approach of how a language should be taught does not exist. It has been claimed that second language teacher education should focus on the teacher's teaching abilities rather than on linguistics and language acquisition (Freeman \& Johnson, 1998). However, others

\footnotetext{
${ }^{2}$ To clarify, a second language should not be mistaken for a foreign language. Whereas a foreign language is a language predominantly learned in a context, separated from arenas in which the language is used, e.g. studying German in Sweden, a second language is learned in an environment in which the language is widely used for communication in daily life.
} 
such as Tarone and Allwright (2005) object to this idea. They state that second language teaching and learning are different from other types of educational practice and should be based on research in a second language teaching and learning context, not just on overall teaching. Unlike Freeman and Johnson, they hold that knowledge about second language acquisition is essential for a teacher in this context. The teacher should know who the learners are, what they need to know and how to negotiate learning activities with them (Tarone \& Allwright, 2005). A parallel can be drawn with LESLLA teaching. For adult emergent readers, it is a bigger challenge to develop print literacy in a second language, of which they may not have as much phonological and phonemic knowledge. Also, with a small vocabulary, the reading cannot be facilitated by the reader recognizing the words (Boon, 2011, p. 264). This knowledge about the learners can be crucial for the choices in teaching.

The other area of second language teacher competency is having knowledge of the immigrant and refugee experience. That most learners in second language education have such experiences presents a challenge for the teacher, which concerns not only the teaching. There are many other things than learning a language that immigrant or refugee students struggle with. They may have lost family members and professional positions, and they must make efforts to become established in the new society. As a consequence, refugee teachers picture themselves as mentors, counsellors and challengers, etc. (Magro, 2008, p. 28, 30).

A third area of competency deals with the teachers' attitude to the learners. There is a risk that teachers alienate the learners in the classroom as a consequence of ethnical and cultural differences. In her study of female LESLLA learners in SFI, Lundgren (2005, pp. 180-182) shows that a technical approach with narrow and nonauthentic questions was prevailing in the training of literacy skills. Seeing the value of student-centred discussions, one of her conclusions is that the school should instead recognize the learners' cultures and their experiences. This would support the literacy and Swedish language development process. Another study (Zachrison, 2014) illustrates how immigrant students in basic adult education experience a sense of non-belonging when they use the Swedish language inside and outside the classroom. One reason is the monocultural norm that predominates in the pedagogical context, 
and that is more about fostering societal norms than developing communication skills. In Carlson's thesis (2002) on how knowledge and learning are organized and formulated by SFI and how the learners experience the education, the author gives a similar picture. The SFI students are described by teachers, and by other groups such as policymakers, as ignorant and weak, since they do not 'fit' into how the 'majority society' conceptualizes what it means to be a part of Swedish society. According to such a deficient perspective, the role of native Swedes, the teachers, is to foster the learners and decide what is best for them. Even if the teachers explicitly dissociated themselves from this kind of opinion, they used a terminology that reflected the existence of such a discourse. Thus, the social structures on the macro level are not separated from the teachers at a micro level (Carlson, 2002).

\section{Mother tongue teaching}

"Mother tongue teaching" is the term usually used to refer to the opportunity that bilingual children are given in school to develop their mother tongue, even if it is not the official language of the country of residence. In the compulsory school in Sweden, it is given as a particular subject (see e.g. Swedish National Agency for Education, 2016a). In LESLLA teaching, in contrast, the term is used to refer to teaching in the mother tongue, using it as a tool for the students' literacy and second language learning (Swedish National Agency for Education, 2016b).

With respect to the language(s) used for instruction, bilingualism is a relevant concept ${ }^{3}$. It has been applied to describe the ability to use two different languages (Garcia, 2009, p. 4). There is, however, also a more elaborated interpretation of bilingualism. In this case, it is used, at least when it is regarded from the user's perspective, to denote translanguaging, i.e. "multiple discursive practices, in which bilinguals engage in order to make sense of the worlds" (Garcia, 2009, p. 45). Consequently, it is a way to create

\footnotetext{
${ }^{3}$ NB! The terms "bilingualism" and "multilingualism" can be used interchangeably (see Bhatia, 2017). Thus, when I use the word "bilingual", it can refer to the use of more than two languages.
} 
meaning and facilitate communication between the people involved in a practice. The use of a mother tongue in the teaching of second language learners has been promoted in different studies. Thomas and Collier $(1997 ; 2002)$ and Cummins (2015) show a connection between this and academic achievement. Although their research is based on children, they argue that the support of a mother tongue in education is of benefit for adults too. Moreover, bilingualism implies cognitive and social advantages, such as metalinguistic awareness, creative thinking, cultural awareness, and the ability to interact with others locally and globally (Garcia, 2009, pp. 94-100).

However, not everyone agrees that mother tongue teaching is the best alternative for orally literate adults. Sachs (1986, p. 66) shows in her study of immigrant women from rural areas in Turkey living in Sweden who were taught initial literacy in their mother tongue that the print literacy skills of the women were low in spite of 2,000 hours of initial literacy teaching. This leads her to raise the questions of whether it is more difficult to learn print literacy in a known language, and whether it would have been a better option to teach literacy in Swedish, instead. Nonetheless, Sachs acknowledges that the students' modest progression could have been related to the women's negative attitudes to the variety of Turkish used in the reading material, and to the fact that the women did not see the point of using print literacy in their everyday life.

\section{Mother tongue teachers and teachers with an immigrant background}

Since there are mother tongue teachers within the LESLLA education, this section summarises what research says about issues specifically related to their professional identity. This includes research on teachers with an immigrant background.

Research on mother tongue teachers in the compulsory school illustrates how their subject is often marginalized, both in the public debate and in the local school context (Narrowe 1998, p. 68; Ganuza \& Hedman, 2015, p. 136; McCarty, Collins \& Hopson, 2011, p. 343). This reflects that different languages are given different status in the school context.

Other studies highlight that a teacher's language and ethnical 
background contribute to the formation of her/his professional identity. A study of bilingual teachers in the Swedish school system shows that even if the teachers constructed their new professional identity on the basis of their subject of teaching and pedagogical strategies, their immigrant background also contributed to how they described themselves as teachers. It was considered both as a disadvantage and a resource. With regard to native colleagues it could, sometimes, be marginalising, whereas it was viewed as an advantage in the meeting with for example the students, who also had an immigrant background (Rubenstein Reich \& Jönsson, 2006, pp. 102-103). Bigestans (2015), moreover, investigated how immigrant teachers establish themselves in the Swedish school system, and she brings up challenges the teachers face in the process. Apart from struggling with the language and a new community of practice of the school, the teachers sometimes experienced that their colleagues and the parents of the students considered them to be less qualified than Swedish teachers. Such negative experiences can be related to language hegemony. Holliday (2006, p. 385) writes about native-speakerism. The underlying perspective of this concept is that the native-speaking teacher is both linguistically and pedagogically superior than the non-native speaking language teacher and learner. This leads to doubt whether teachers with another mother tongue are able to teach the language as well as a native speaker.

There are different strategies for a teacher, who due to her/his immigrant background and/or to her/his position as a mother tongue teacher experiences alienation and marginalization. Bredänge (2003) analyses the strategies that immigrated teachers need to 'translate' their professional skills to the circumstances of the Swedish school. She finds that the most fruitful strategy to gain satisfaction with oneself and be accepted by the surrounding community is to balance the old ways of doing things with the new, rather than to trying to assimilate oneself completely or to continue doing what one had done before in one's former school system. Simultaneously, however, the 'receiving school' also needs to take care of different competencies and be open for reconsidering its routines (Bredänge, 2003, pp. 96-98). Rubenstein Reich and Jönsson (2006, pp. 103-104) point out that the bilingual teachers' professional identity is constructed by distinguishing oneself from 
the native teachers in a positive sense. Such an emphasis on ones' abilities indicates a need of being legitimised in the Swedish school.

Another study (Valenta, 2009, pp. 30-31) illustrates that some teachers seek to defuse their bilingual teacher identity by looking for other types of teaching role in the school system. Such teachers may also wish to pursue more higher education to obtain higher status. A study of mother tongue teachers showed a similar finding - that younger teachers struggle for legitimacy through getting further education, even if they already have sufficient education for the position they hold. At the same time, a strategy among the older teachers was to highlight the qualifications they had obtained in their native country, to avoid a feeling of inferiority (Ganuza \& Hedman, 2015, p. 128).

\section{Perspectives on initial literacy teaching}

That the LESLLA teacher teaches initial literacy is one thing that distinguishes her/him from other second language teachers within adult education. According to Williams and Snipper (1990, p. 12), teachers must understand how they conceptualize literacy themselves, in order to be able to develop the students' literacy. This may influence the methods they apply in their teaching and the expected outcomes. In this section, I present some common conceptions of literacy and show the implications that they have for literacy teaching.

For a long time, the term "literacy" was used to describe simply the ability to read and write, especially the former. This view is echoed in what is known as "functional literacy", which refers to the ability to read and write well enough to manage everyday life (Williams \& Snipper, 1990, p. 4). The functional skills-based perspective implies that literacy is regarded as something individual and cognitive (Tett \& St. Claire, 2010, p. 107108), and there has been much debate about the most useful methods to "solve" students' difficulties in reading and writing (see Luke, 1998, pp. 305-306).

However, the skills-based and cognitive outlook on literacy has been challenged by another perspective, which reconverts literacy into an autonomous skill. Instead, it is to be understood 
from an ideology model. From such a perspective, literacy is related to one's knowledge and how one understands oneself, at the same time as it is a social practice evolving in a socio-historical context (Street, 1984). According to such a cultural view of literacy, while reading or writing a text, one constructs the meaning of it. What the readers bring to the reading is related to their background, experiences and values (Williams \& Snipper, 1990, pp. 6-7). This perspective is seen in research on initial literacy teaching. To become literate assumes active learning in which the learner seizes the tools of literacy, and it requires a space of reflections and questions for the learners and the teachers. A dialogue that moves between formal learning and the everyday world of the learner is fundamental (Hamilton, Hillier, \& Tett 2006, p. 9). The teachers must take the responsibility of bridging the distance between the school and the everyday life of the learner. Mutual respect and dialogue between the stakeholders in the education, the learners' active participation in the learning, and meaningful content, methods and material are important keys to success in this (Franker, 2013 , p. 801). It is also important to use authentic materials for everyday life that comprise information that the students have some experience of, or want to know, for example letters from societal institutions or flyers from shops (Condelli, Wrigley, \& Yoon, 2008, pp. 152-153).

With the digitalisation of society, multimodal literacy has become a factor in LESLLA teaching. In short, multimodal literacy involves information transfer by image-based media, not only reading letters. (Kress, 2003, pp. 1-2). Thus, to become literate one must develop visual literacy - the capacity to read pictures (Franker, 2007, p. 2). While there is one type of logic behind writing, characterized by, for example, encountering sequences in a certain order, another type of logic operates behind the reading and creation of a picture. It implies that one needs the logic of depicting elements spatially related to each other (Kress, 2003, pp. 1-2). Moreover, according to the multimodal stance on literacy, there are a number of organised sets of semiotic resources - modes - which are used to for example create and distribute meaning. Image as well as body language and speech are examples of modes that contribute together to make meaning. Teaching advice based on research on multimodal literacy suggests that teachers must include 
the students' multimodal literacy practices and build on these to deepen the students' understanding of multimodality (Jewitt, 2008, pp. 246-247, 259-263).

\section{Perspectives on emergent readers}

The perspective one has on initial literacy learners comes, at least partly, from the perspective one has on literacy and literacy teaching. It gives a clue to understand the teachers' conceptions of the learners and their attitudes to them, which are central aspects of such matters as the second language teacher competency.

Studies based on a cognitive perspective point out differences between oral literates and print literates. Goody and Watt (1963, pp. 344-345) outline how the development of written literacy communities has implied more analytical ways of understanding the world. Following a similar line, Ong (1982, pp. 36-48) claims that the thoughts and expressions in an orally literate community, in contrast to the ones in a print literate community, are for example aggregative rather than analytic, empathetic and participatory rather than objectively distanced, and situational rather than abstract. More contemporary studies on LESLLA learners based on a cognitive perspective illustrate how oral language is processed. Generally, alphabetic print literate people are found to more easily than oral literates be aware of and manipulate language segments, such as words, syllables and phonemes - things that have to do with language forms rather than language meaning (see Tarone, 2010, p. 76.) Moreover, when it comes to second language learning, the learner's level of literacy skills, in particular, plays a certain part. The ability to combine a phoneme with a grapheme influences one's ability to orally process a second language (Tarone, 2010, p. 80). Also, alphabetic literacy can for example have implications for one's metalinguistic awareness and may serve to strengthen one's short-term memory for language (Bigelow, Delmas, Hansen \& Tarone, 2006, p. 684, 686.)

However, some studies that have claimed that such differences exist have been criticised for being carried out from a Western and alphabetic perspective, raising the possibility that they were unable to properly explore orality (Collins \& Blot, 2003, pp. 
14, 15-17). Further, it has been called into question whether the ability to read and produce alphabetic texts leads to the development of cognitive skills useful outside the specific cultural context in which this ability has been acquired (Gee, 2011, pp. 6465 ) and it has been suggested that holding a deficit perspective of oral literates may not be useful (see Tett \& St. Claire, 2010, p. 108). The focus on the differences between literacy and orality may be a result of interpreting literacy as autonomous skills, an interpretation that neglects social and economic conditions and regards literacy as the solution to poverty. By learning literacy, individuals are regarded to develop cognitive skills and improve their lifesituations, regardless of the broader social structures that underlie illiteracy among adults (Street, 2003, p. 77).

Some studies seem to both use and criticise ideas from different perspectives of literacy. Watson (2010) uses the word "abyss" to illustrate the great distance between orally literate English language learners in American high schools and contemporary US culture, which was reflected in their educational programme. But at the same time, she is not uncritical of Western literacy. For the sake of the learners, for the teachers, and for others who are part of a Eurocentric culture, Watson advocates a reciprocity of orality and literacy in teaching. The teachers are to teach literacy in a way that ensures that the learners can survive in the hyperliterate society, but at the same time they themselves should learn from the lifeworld of orality for the sake of Western society's survival. In another study based on the literacy practices of adults with no or little formal schooling, Perry and Homan (2015) revisit the often-criticized idea of functional literacy and highlight that it is being used not only for economic reasons, but also for personal development. They find that functional literacy is a tool that adults use for psychological or spiritual development, for challenging or escaping problematic situations or experiences, for developing their sense of heritage or identity, and for being able to get pleasure and/or relax in privacy. Thus, literacy teachers should consider the learners' goals with literacy and invite them to literacy practices that are relevant to them (Perry \& Homan, 2015 pp. 449451).

The outlook of adults who have not obtained the opportunity to develop print literacy is reflected in the terms used for 
categorizing them. In the LESLLA teaching context, Bigelow and Vinogradov (2011) call them "emergent readers". Instead of using words such as "pre-literate", "illiterate", or "non-literate", which signal a deficit perspective of the learners and a view of literacy as a fixed state, the term "emergent readers" has the advantage of reflecting literacy learning as a process in which the learners are engaged (Vinogradov, 2011, p. 121).

\section{Being a teacher of LESLLA learners}

There are a limited number of studies that deal with the LESLLA teacher in particular, but two major and closely related themes can be seen: teacher competency in regard to the particular nature of the learners, and the teachers' own professional learning.

According to Vinogradov (2013a), the LESLLA teacher should have a general understanding and skills of teaching, at the same time as s/he should have knowledge of language, language acquisition and the immigrant and refugee experience. In that sense, LESLLA teacher competency resembles that of a second language teacher in general. But something that makes LESLLA teaching more difficult is that the teacher has seldom experienced her/himself what it means to learn print literacy as an adult. The teacher's and the learners' different experiences of education and literacies may imply that they have totally different understanding of the language learning process (Bigelow \& Vinogradov, 2011, p. 120).

Something that complicates the teacher's ability to learn LESLLA-specific teaching is the fact that there is little research on initial literacy teaching for adults. As a consequence, the teacher is to glance at approaches designed for teaching initial literacy to children, and have the ability to adapt these to the context of adult learners (Vinogradov 2013b). Franker (2007), moreover, illustrates what kinds of conception the pictures that teachers use in initial literacy teaching reflect. Teachers often underestimate the capacity of the learners and come to infantilize them as seen in such matters as the use of simplified pictures. Another belief found among the teachers is that the difficulties students have in interpreting the pictures in the intended way is a consequence of their problems of 
perception. The teachers do not consider that the learners can be unfamiliar with the codes of image interpretation in the Western school context. Also, the pictures used tend to alienate the learners, since the author believes that the learners cannot understand the pictures because of their cultures. This reflects a stereotyped dichotomy of 'us and them' (Franker, 2007, pp. 104-106). Consequently, LESLLA teacher competency is, as is the case for second language teachers in general, much about the outlook one has towards the learners. The teachers should consider the resources of the learners - their knowledge, language and experiences - and link the initial literacy teaching activities to these (Franker, 2013, pp. 798-801).

Whereas some studies mainly point out what the LESLLA teachers should learn, other studies focus on how they can develop. Farrelly (2012, pp. 167-168) advocates co-operative and easily accessible ways of learning such as study circles and peer observation. These contribute to the local knowledge production in LESLLA teaching, promote feelings of belonging for teachers, and help them to develop things collectively. Along the same line, Perry and Hart (2012) promote opportunities for the teachers to learn in their relationships with other people in the field, for example having a mentor, gaining access to experts in the field, and participating in a network to share experiences. Moreover, they value in-service training, in which one makes use of the teachers' own context to identify topics for learning and draw on the knowledge they already possess. Finally, also the role of self-education, and thus the importance of access to for example books, teaching tools and teaching ideas is stressed (Perry \& Hart, 2012, p. 120-121).

Research on LESLLA teachers illustrates that the learners in their capacity of being second language learners and emergent readers call for specific competencies, whereas the ways in which they can develop these are not exclusive to this type of teacher.

\section{Implications from previous research}

Previous research serves as a preunderstanding in my exploration of what it means to be and become a LESLLA teacher. It highlights that many issues contribute to a professional teacher identity: for 
example the individual agency and experiences, the specific setting, the cultures/communities of different educational institutions, the social interactions at the school level, and broader social structures like language hegemony and discourses on professionalism.

The review of previous research given above illustrates the complexity of the LESLLA teacher profession. The teachers must have competency in many areas. Being a LESLLA teacher is to be a teacher of adults, of second language learners, of immigrants and/or refugees, and of emergent readers. In each field, there are practices and discourses on competency and teaching to which the teachers must relate. For example, the different notions of literacy and conceptions of emergent readers reflect the ambiguousness of the field of initial literacy teaching.

In spite of this complexity, research on LESLLA teacher identity is deficient. Few studies have explored the multiple roles of the LESLLA teachers and how they continuously learn their profession. Studies on teaching and learning that include the concept of initial literacy concentrate more often on learners than on teachers. Alternatively, they say something about how initial literacy should be taught or, as shown in the introduction, focus on the work conditions of LESLLA teachers.

Many of the studies described in the survey above reflect other contexts than the Swedish, where this study is located. But in spite of differences in for example curriculum and regulations concerning teacher qualifications and employment, there are many similarities of LESLLA teachers across countries. In the Western context, initial literacy teaching is characterised by the learners, commonly, having an immigrant or refugee background, and must not only develop initial literacy but also learn a second language. In the case of adult education, moreover, there are similar tendencies of professionalisation and standardization.

The focus of this thesis on LESLLA teachers does not mean that it is irrelevant to other groups of teachers and types of teaching. Since teaching within adult education and teaching a second language are companions to LESLLA teaching, the study has implications also for teachers who work in these broader fields. Likewise, the study can add something to the phenomenon of professional teacher identity in general.

The substudies of this thesis address different areas. In the 
first paper, teaching is in focus and the paper emphasises the role that learners play for teacher identity. The second paper deals with the teachers' learning when they transfer from other teaching practices to the LESLLA practice. It reflects the specific nature of the LESLLA teaching with regard to other types of educational practice. Paper III focuses on the identity construction of teachers who use the students' mother tongue as a tool in LESLLA teaching, while the fourth paper addresses the LESLLA teacher as a teacher in adult and second language education and in regard to change within these fields.

Many different terms are used to describe teachers' identity process, including development, formation and construction. In addition, this is a concept explored from many theoretical perspectives and with many methodological approaches (Beauchamp \& Thomas, 2009). In this study, I use the term "identity formation" when I refer to how a teacher undergoes changes as a professional in general, and "identity construction" when speaking about how s/he actively negotiates her/his professional identity. Such a definition is not explicitly stated in the main theory applied in this thesis, but it corresponds with it as a whole. 


\section{Theoretical perspectives}

In this chapter, I introduce the theoretical perspectives and concepts I use to analyse my findings. I begin by presenting the main theory, situated learning, which I have chosen since it deals with identity formation and is often used for studying identity in professional contexts. Then I discuss common criticisms raised against the theory.

Apart from the concepts notions brought from situated learning, I also employ Bourdieu's concepts of field and capital as thinking tools. By combining them with situated learning I can better comprehend power as an element that contributes to the teachers' identity formation. It is true that the Bourdieuan perspective and situated learning differ, for example in terms of whether identity is regarded as fully situated or something that depends on one's previously developed dispositions (Handley, 2006 , p. 647). Both, however, consider social processes to be the basis for the production of learning and knowing (Nicolini, Gherardi \& Yanow, 2003, p. 15), which is what identity is about (Lave \& Wenger, 1991). Certainly, the perspectives have different entry points. Where Bourdieu aims to see how power relations are reproduced, situated learning deals with learning. But power plays a part in learning and the social structures in the learning process can contribute to the reproduction of power relations (Farnsworth, Kleanthous, \& Wenger-Trayner, 2016, p. 14).

In the final part of this chapter, I state some implications that the framework I have chosen has for the study.

\section{Foundations of situated learning theory}

The situated learning theory was introduced by Lave and Wenger in the beginning of the 1990s in Situated learning: Legitimate, Peripheral Participation (Lave \& Wenger, 1991) and later on in Communities of Practice: Learning, Meaning and Identity (Wenger, 1998). There they outline how learning involves the whole person; her/his actions, agency and understanding of the world. This implies 
that the context in which the person engages is of great importance. Learning is always situated in particular contexts and evolves when one gradually comes to engage with a certain community of practice. Since learning involves the complete person and not just for example one's cognition or ability to perform a skill, it is also identity in formation. It requires becoming a full member of the communities of practice one participates in (Lave \& Wenger, 1991, pp. 52-53). "Learning thus implies becoming a different person with respect to the possibilities enabled by these systems of relations" (Lave \& Wenger, 1991, p. 53).

A community of practice is "a set of relations among persons, activity, and world, over time and in relation with other tangential and overlapping communities of practice" (Lave \& Wenger, 1991, p. 98). The emphasis on practice in a community can be understood from what characterises it: a mutual commitment for a joint enterprise and a shared repertoire. The mutual commitment means that the interactions with other members are central, whereas a joint enterprise implies that there is a shared idea of what the community is about and a mutual responsibility taken for it. Moreover, the shared repertoire is common resources that reflect the history of the community (Wenger, 1998, p. 83). The latter consists of various artefacts, both physical (such as tools and documents) and conceptual (such as stories, methods and concepts) (Wenger, 2010, p. 180).

Also, there is an ongoing production and reproduction of a community of practice. Lave (1991) writes that "the relations between the social world and persons engaged in activity ... produce and reproduce both world and persons in activity" (p. 67). The production and the reproduction are intertwined processes, where artefacts are produced and used (Wenger, 2010 pp. 1-2.)

\section{Identity formation in a community of practice}

An advantage of using situated learning theory in this study is that learning implies identity formation (Lave \& Wenger, 1991, p. 53). The perspective has introduced the idea of identity development through legitimate peripheral participation (lpp). This means that a newcomer to a community of practice gradually learns from more 
experienced colleagues, "old-timers", by participating in the different activities of the community. Some of these, those who are not yet masters but are more used to the practice than the newcomers, are called relative old-timers (Lave \& Wenger, 1991, p. 57). The relationship between a newcomer and an old-timer can be compared to the one of an apprentice and a master, and this implies that the old-timer does not necessarily influence the learning of the new member directly. Rather, s/he plays a critical role by giving access to the community (Lave, 1991, p. 68). The word "legitimate" expresses the right to belong - a necessity for learning. The term "peripheral", on the other hand, indicates that there is a direction towards the centre of the community of practice for the member's trajectory (Lave \& Wenger, 1991, pp. 35-37). Thus, the learning process does not just contain knowledge development and a new way of doing things. It is also about one's position in the community.

However, later contributions to the theory highlight that not only newcomers learn (Wenger, 2010, p. 3), and that learning therefore can go beyond lpp. But in any case, identity is entangled with participation in a practice. Wenger (1998, p. 149) highlights how the past, as well as the present and the future, is part of one's identity: "We define who we are by where we are and where we are going". He connects identity not just with participation, but also with reification. Generally, reification is about turning something abstract into something concrete, treating it as an object in order to understand the world. In that sense, Wenger (1998, pp. 58-59) uses it for processes such as describing, interpreting, making and using something in a practice. This means that reification also includes how a member, through negotiation, experiences her/himself in the practice. It is there, s/he comprehends what for example the stories, roles and positions within it imply (Wenger, 1998, pp. 150-151). The stories and the other abstractions of the practice, symbols and concept, etc., and artefacts such as textbooks and policies, are also examples of reifications. They influence how one experiences the world and they can change the nature of a certain activity (Wenger, 1998, pp. 58-59).

Related to identity and practice is also the concept of "regime of competence". In any community of practice, there is a negotiation of competence and the member is accountable to the 
competence that is claimed to be valid. Consequently, competence is more than a personal feature; it is something acknowledged by the community. Learning is to align and realign both with the competence of the practice and one's personal experiences. Successively, members' experience becomes in line with the regime of competence, and, simultaneously, the regime is formed by their experience. Members can find new ways of acting that the community may find superior to the previous practice (Wenger, 2010, pp. 2-3; Wenger-Trayner \& Wenger-Trayner, 2015, p. 14). Moreover, a member's claim to be competent can be either accepted or rejected by the community, at the same time as the member can embrace or reject the competence regime by being accountable to it or not. The latter depends on whether they want to belong or not. It is a work of identity (Wenger, 2010, pp. 2-3).

\section{I dentity formation in a landscape of practices}

To conceptualise the number of different communities that a professional worker identifies with, the metaphor of a journey in a landscape of practices has been launched. The notion highlights that identity formation is not solely a matter within a single community of practice. Rather it is something that evolves in a whole system of communities and in their boundaries. Such a landscape can be compared to a profession made up by a number of different communities of practice. In the case of this study, there are communities of teaching and learning, work teams and other local school practices as well as a more overall community of LESLLA teachers. The landscape is undergoing constant change since new communities arise and others disappear. Each community produces its own meaning and the relationships between different practices must be negotiated. In some cases, this causes conflicts (see Wenger-Trayner \& Wenger-Trayner, 2015, pp. 15-16). Since individuals keep a sense of agency through the life trajectory, they will experience inner tensions when what membership of one community implies does not correspond with what it does in another. Moreover, this means that identity is not developed solely within the communities, but also between communities, at the boundaries (Handley et al., 2006, p. 650). 
Often, identity from a situated learning perspective is understood with regard to the communities in which one personally participates. It is regarded as identification through engagement and implies members acting and talking together and the production of artefacts (Wenger-Trayner \& Wenger-Trayner, 2015, p. 20). Identity in this sense, is becoming someone and belonging to a particular community (see Handley et al., 2006, p. 644). However, whereas engagement is about doing things together and, thus, learning what one can do and how the world replies to it, there are also other modes of belonging, in the landscape of practices. Identification through imagination happens when people create an image of themselves as a part of a community. It does not require such a direct context as a community in which one immediately participates (Wenger, 2003, p. 78; Wenger-Trayner \& WengerTrayner, 2015, p. 21). For example, a teacher can imagine that s/he is a part of a general teacher community and not just of the communities of teachers in her/his school.

Alignment, on the other hand, is related to how one ensures that one's actions are in accordance with for example regulations or intentions in a broader context (Wenger, 1998, p. 179), as well as with a local regime of competence (Wenger-Trayner \& WengerTrayner, 2015, p. 22). Alignment is a condition for engagement, but even so, it does not imply a passive adaption to rules and regulations. It means negotiation in order to ensure that one's actions in the local community and the regulating perspectives lead to the goals that the community is striving to reach (Wenger, 2003, p. 79).

The three modes of belonging can operate alongside each other in a community, or across communities. Whereas there will be teachers who more strongly identify, or dis-identify, with for example their school community, others may feel more connected, or disconnected to their subject of teaching (see Wenger-Trayner \& Wenger-Trayner, 2015, p. 22).

\section{Criticism of situated learning theory}

Despite being applied to a vast number of contexts, the original version of situated learning theory has been criticised for a number 
of things. For one thing, it neglects that gender has an impact on the identification process and access to the community (SalminenKarlsson, 2006). For the aim of this study, however, there are other criticisms, which are more crucial to relate to. One of these is that Lave and Wenger put too strong an emphasis on newcomers' learning. Even old-timers are learning, both from newcomers (Fuller, Hodkinson, Hodkinson, \& Unwin, 2005, p. 64) and from the impact of wider influences from the society (see Billett, 2006, p. 61).

Another point of criticism is that Lave and Wenger ignore individual differences (Billett, 2006, p. 61). There is a lack of attention to the single member's subjectivities and life experience (Billett, 2007, p. 65) and the personal dispositions developed from these (Hodkinson \& Hodkinson, 2003). A newcomer in a community is not a blank slate, but is faced with the task of placing her/his previously developed skills, values and comprehensions relative to the community. Individuals' prior knowledge, skills and ideas influence how their identity in a new community is formed (Fuller et al., 2005, p. 66). By the notion of participatory practice, Billett (2004, p. 109) highlights that a workplace community provides different opportunities for participation and learning, and that each member responds to them in various ways. The responses are related to the members' personal biographies, which have been shaped by their participation in different communities. The personal history determines how one understands the social world and engages with it. By considering that a person is never separated from his/her history, it is easier to understand the negotiation of identity that takes place when individuals adapt themselves to different communities. Closely related to individual history is criticism of the omission of individual agency. By acknowledging individual agency, one contests the idea that learning is completely situated. According to Billett (2006) "human agency operates relationally within and through social structures, yet is not necessary subjugated by them" (p. 63). Individuals are socially shaped, but in ways that depend on how they have previously personally constructed themselves (p. 63).

However, agency is not something that can be related only to a single worker. According to Hökkä, Vähäsantanen, and Mahlakaarto (2017, p. 38), there is collective agency, which is 
"enacted when professional communities exert influence, make choices, and take stances in ways that affect their work and their professional identities".

In addition, the fact that a person is never separated from her/his history implies that her/his membership in multiple communities causes tension both for the individual member and for the community (Handley et al., 2006, p. 650). Engagement in a community can be paved with conflicts (Fuller et al., 2005, p. 66).

A final criticism directed towards situated learning is that it does not elaborate on the role of power (Fuller et al., 2005, p. 66). Wenger has responded to this criticism to some extent. He points out that power is an issue inherent in situated learning since it is a social theory. The regime of competence implies that a member's competence is not necessarily legitimate, and not every member is legitimated to change the competence regime. Members claim certain competencies and struggles over them (Wenger, 2010, p. 8). However, to further consider the aspect of power with regard to identity, I have also included Bourdieu's concepts of field and capital. As previously stated, the social process in learning is central in both perspectives (see Nicolini, Gherardi, \& Yanow, 2003, p. 15) and power relations can be reproduced within it. In that sense, Wenger states that the Bourdieuan concepts very well can be combined to the perspective of situated learning (Farnsworth et al., 2016, p. 14) and there are other studies that explicitly combine notions from them (see e.g. Hodkinson \& Hodkinson, 2004; Ollis, 2011).

\section{Field and capital - complementing situated learning with Bourdieuan concepts}

Field is a notion that can be clearly related to the landscape of practices. Hodkinson and Hodkinson (2004, p. 29) apply the term "community of practice" to a close-knit community that expresses mutual commitment for a joint enterprise and a shared repertoire, as described by Wenger (1998). The authors, however, also draw on Bourdieu's concept of field, talking about a "learning field" or "field of practice" for describing the many overlapping levels of interaction of which teachers are part. Although the landscape of 
practices comprises a political aspect, in which different communities compete or may be silenced in their claims of knowledge (see Wenger-Trayner \& Wenger-Trayner, 2015, pp. 1516), the notion of a "field" implies a stronger emphasis on power. A field is compared to a game, where different agents, collectively and individually, position themselves relative to the capital they have (Bourdieu, 1998, p. 32). The capital comprises tools, which are used in the struggle to preserve or change the structures of the field. At the same time, since the forms of capital determine the agents' position in the field, their value is at stake (Bourdieu \& Wacquant, 1992, p. 98).

Capital may be economic, social or cultural. The cultural capital appears in three states. One of them is the institutionalised state, which refers to educational qualifications. Another is the embodied state, which is capital incorporated in a person, longstanding dispositions connected to body and mind (Bourdieu, 1996, p. 106). To speak the official language is an example of embodied cultural capital. A legitimised way of speaking may be necessary for being acknowledged in a social domain (Bourdieu, 1991, p. 55). These forms of capital make up symbolic capital, provided that they are recognised and valued. The values of the forms of capital, however, are not constant. The exchange rate between different types of capital can change, not least when the current balance between the bureaucratic instances in control of the exchange rates are rocked (Bourdieu, 1998, pp. 32-34, 47). Closely related to capital is the notion of "habitus". Embodied capital is described as habitus, but at the same time habitus is not necessary capital. The difference is that capital is always ascribed a value (Broady, 1991, p. 226). However, since the Bourdieuan concept is only used as a complementary thinking tool and to delimit the study, I will not include habitus in the analysis.

The notions of field and capital add on to the regime of competence in that they not only acknowledge that there is negotiation of different competences in a community or a landscape of practices. They also illustrate how different types of competence are set against each other, and that wider social structures, and not just the mutual enterprise of a community, determine what competence is valued (see Farnsworth et al., 2016, p. 13). In this 
sense, these concepts are useful as thinking tools, as a complement to the theory of situated learning.

\section{Theoretical implications for this study}

The theory of situated learning is applied in all substudies of the thesis, but the four research questions partly require different aspects of the theoretical framework. Thus, in this section I will start to describe how I use the concepts with respect to my aims and research questions.

The concept of a community of practice forms a foundation of the thesis, since it says much about identity. In line with it, I view identity as a dynamic concept. Generally, the landscape of practices is also crucial, since it illustrates an overall professional teacher identity in regard to the identities the teacher holds in the different communities. An overall point of departure is that the LESLLA teacher belongs to many different communities, for example the teaching and learning practice, in which s/he participates together with the students, a variety of other local school practices that scaffold the teaching, and wider professional communities with which s/he identifies and aligns. Thus, the term "practice" is used in the singular when I refer to one particular community, whereas the plural "practices" refers to teachers' membership in more than one community. The latter is useful, for example, when using the notions of field of practice and landscape of practices. Another concept central for all questions is that of negotiation. This is used to understand how the teachers act and reify their participation in regard to for example their learners, changes in learning opportunities, and capital. The teachers construct their professional identity through negotiation.

Some notions are used more exclusively to answer a particular research question. The first question is about the teachers' actions in regard to their conceptions of the learners. Here, one singular community, the teaching and learning practice, is in focus, and the notions of newcomers and old-timers show how this practice is reproduced and produced. These notions also show how attempts to adjust to the new community create tensions. Artefacts, moreover, are regarded as the tools that teachers use in teaching. 
The three other research questions are analysed from the premise that the teacher has many memberships, i.e. identifications with different communities. When answering the second question how teachers used to other types of teaching learn the practice of LESLLA teaching - I also found participatory practice helpful. It shows the relationship between the teachers' individual agency and the context they are a part of - how teachers take different opportunities for learning depends on their personal biography.

The analysis of the third question - how bilingual immigrant teachers in the field of LESLLA teaching construct professional identity - rests not only on the concepts of imagining and aligning; it is informed by Bourdieu's notions of field, dispositions and capital. Imagining and aligning help to illustrate how a teacher can identify with many communities in different ways, whereas the notion of field sheds light on how the social structure of language hegemony contributes to teacher identity within the landscape of LESLLA. Moreover, the use of capital, especially institutionalised and embodied capital, provides an opportunity to see how teachers negotiate competence.

The fourth question deals with teacher identity in regard to societal and workplace changes. Here, alignment and the regime of competence serve to explain why teachers respond to the changes in a certain way, something that is in turn related to their individual and collective agency. 


\section{LESLLA Education in Sweden}

This study concerns second language and initial literacy education for adults. In spite of similarities in the profiles of the learners across different educational practices within this field, there is a great variety in how it is organised. In many countries, the LESLLA teachers are volunteers, whereas they are employed in others. Sometimes the education is organised and/or completely supported by the government. In other locations it relies on community-based initiatives, with more or less support from the state (see e.g. Sava \& Lupou, 2009). The titles of the people who teach in a LESLLA setting imply different roles. The term 'literacy trainer' or 'literacy facilitator' often signals a volunteer aspect and a certain approach of teaching and learning, whereas the term 'teacher' rather reflects more formal work conditions.

Since this study proceeds from a Swedish context, I will give a brief overview of the SFI system, in which LESLLA teaching is offered. Also, I will summarize what the curriculum and another policy document stipulate about the LESLLA teachers' mission and bring up some major changes that have influenced LESLLA teaching.

\section{The educational system of SFI}

In the Swedish welfare state, education, generally, is something public and the teachers are formally employed. To be authorised as an SFI teacher, one must have a teaching degree for the compulsory school or the upper secondary school, and at least 30 credits in Swedish as a Second Language (Swedish National Agency for Education, 2017d). Among other things, authorization means that the teachers can grade students and be employed on permanent contracts. Schools have been exempted from the requirement to employ authorized mother tongue teachers. This means that nonauthorized mother tongue teachers can be employed, if they are considered to be fit for the position and there is lack of authorised mother tongue teachers (Swedish National Agency for Education, 
2015). Nonetheless, one can apply for an expanded authorisation and qualification to teach a mother tongue. The applicant is then to speak a certain language as a mother tongue, have an education that qualifies her/him to teach according to the constitution of qualification, and have 30 credits or more in the language in question (S. Lundberg, Swedish National Agency for Education, personal communication, June 28, 2016).

SFI is regulated by a national curriculum. The main aim is that the students should develop basic and functional skills in the Swedish language. However, like a majority of the adult educational initiatives in Sweden, one of the purposes is also to prepare workers for the labour market (see Swedish National Agency for Education, 2016b).

There are four courses in SFI. There are three study tracks, and the one taken depends on a student's educational background. Learners with little or no formal schooling are offered study track 1, which consists of the basic SFI courses A and B. After completing the $\mathrm{B}$ course, they can go on to the $\mathrm{C}$ and/or the $\mathrm{D}$ course, but only few students do so. In 2016, for example only 5\% of these who began with the course A in study track 1 completed all four courses in the SFI education (Swedish National Agency for Education, 2017e). The course of initial literacy can either be combined with some of the courses or studied separately.

Swedish is the main language of instruction, but the students can be taught literacy in their mother tongue or another language they master (Swedish National Agency for Education, 2012, p. 9). Likewise, the students' mother tongue can be used as a tool for Swedish language development (Swedish National Agency for Education, 2016b). Thus, not just SFI teachers, but also mother tongue teachers can be employed within SFI. However, so far, few organizers seem to use this opportunity. From an examination of the public job announcements, available online at the website of the Labour Office, I have found that it is more common that schools employ teaching assistants and/or student counsellors, who speak the mother tongue of a student. Additionally, authorised SFI teachers with a mother tongue teaching qualification in a student language are also desired.

Even if the state regulates the curriculum, the ultimate responsibility for SFI belongs to the municipalities. Many of these 
have chosen to let other organizers run SFI on their behalf. This outsourcing system means that there are a number of different providers in some geographical areas: the municipality itself, private companies, organisations, etc., whereas all SFI courses are organized by the municipality itself in other geographical areas (Ministry of Education, 2013, p. 137, 141).

One potential organizer of SFI are the folk high schools. This is a certain type of a civil educational institution run by NGOs or the county council and, generally, it is known for a participative approach. Since June 2010, the folk high schools, apart from running SFI education on behalf of the municipality, also have the right to apply for permission to set up their own educational equivalent with the municipal SFI (National Centre for Swedish as a Second Language, 2013). In doing so, they do not have to be part of the tendering process (Swedish National Agency for Education, 2016). The folk high schools themselves can decide what formal qualifications they require of the teachers (Andersson, Rudberg, Rydenstam, \& Svensson, 2013, p. 4). They must, however, follow the formal regulations, for example when it comes to assessment and grading in the SFI program (Swedish National Agency for Education, 2016c), which differs from the regulations governing other programmes. Folk high schools that have taken the opportunity to run SFI education have often chosen to give the less basic courses, in which the participants must be print literate in order to be enrolled. From the information given on the webpage Folkhogskola.nu, about 30 folk high schools offered SFI education in October 2017. From reading the information on the webpages of each of them, I found that only around ten of them provided LESLLA education.

\section{The mission of a LESLLA teacher within SFI}

The goal of the SFI education is that the student should learn Swedish, and the focus is on the student's ability to communicate in different ways, orally and through literacy. The education should meet the needs of the student and support her/him to develop a linguistic awareness and an awareness of her/his own communication and learning strategies. Moreover, it is the 
expanded concept of literacy, in which not just printed text, but also for example movies and pictures are viewed as texts, that is promoted. In addition, the curriculum also brings up the goal of learning to use digital tools and to develop intercultural skills for everyday life, working life and society life (National Centre of SFI and Swedish as a Second Language, 2007; Swedish National Agency for Education, 2012).

Another policy document that exists to guide the qualifications of the LESLLA teachers has been drawn up by the Initial Literacy Council of the Nordic Network for Adult Learning. This document focuses on the teachers of adults, second language teachers, and initial literacy teachers (which here also includes mathematics and multimodal texts). The underlying perspectives are that literacy is a social practice and that the learners are people with experiences of literacy, which can be used in the teaching and learning process (Alfarådet, 2013).

\section{The development of the field of SFI and LESLLA}

The current SFI system is the result of many changes, since it is a matter of both education policy, language policy, labour market policy and immigration policy (see Lindberg \& Sandwall, 2007; 2012). During the first 20 years of SFI, it was much more heterogeneous, since there were no national policy documents or criteria for teacher requirements. SFI mainly took place outside the official school system, organised by folk high schools, study associations and vocational employment training courses (Carlson, 2002, p. 21). Not until 1986 was there a curriculum, and some teacher qualifications were stipulated at the same time (Lindberg \& Sandwall, 2007, p. 82).

Many changes, which have made SFI both more uniform and more diverse, have been made since the 1990s. In 1991, the municipalities took over from the state the responsibility for funding much adult education, including SFI. A few years later, an outsourcing system for municipal adult education was introduced (Fejes, Runesdotter, \& Wärvik, 2016, p. 668). The outsourcing system came to affect teachers in several ways. A study of the 
reorganisation of adult education in a municipality in Sweden brings up how a group of LESLLA teachers, who had previously worked for the municipality, obtained the opportunity to start their own school that targeted LESLLA learners and that adopted a certain approach. In that sense, the system opened up for greater professional freedom. At the same time, however, the system created insecurity and uncertainty. The schools could not take for granted that they would have their contract renewed and, thus, the teachers could not be sure that they could keep their job positions (see Beach, 2004, p. 169).

In 1994, a new curriculum replaced the old one and a goalbased system was introduced into SFI. This implied that the municipalities must ensure that the nationally stipulated goals were reached. A negative side effect was that there became less researchbased national initiatives for developing SFI. The state could not interfere to any great extent with the autonomy of the municipalities or with the teachers' opportunities to adopt policy to their work contexts. This, together with the unstable work conditions caused by the outsourcing system, contributed to a reduction in the rate of professionalization of SFI teachers (Lindberg \& Sandwall, 2007, p. $85)$.

In 2010, the Labour Office took over responsibility for coordinating the activities of newly arrived immigrants. The purpose of the reform 'Etableringen' (The Establishment Reform) was to facilitate and speed up the students' process of settling down into working life and society. For SFI, this meant a closer cooperation with the Labour Office (SFS, 2010:197).

Some policy changes have been particularly important for LESLLA teaching. In 2003, SFI education was divided into three study tracks based on the level of the students' previous education and their capacity and goals. Then, LESLLA learners were offered study track 1, in which the pace of progress is slower (Lindberg \& Sandwall, 2007, p. 82). A few years later, the LESLLA teaching received more attention since the regulations now explicitly mentioned literacy tuition. It was stated that literacy tuition should either be offered as a separate course or integrated into the SFI courses, and the language of instruction could be either Swedish or the mother tongue of the student. However, the goals specified for 
this initial literacy course (see SKOLFS, 2006:28) were removed in the following version of the curriculum (see SKOLFS 2009:2).

The frequent changes in the SFI system can party be explained by conflicting perspectives of the role of SFI. Whereas some mean that SFI should primarily meet the demands of the labour market, others stress the role it should play for citizen education and personal development (Lindberg \& Sandwall, 2007). In any case, it is clear from the material presented in this section that the teachers often need to relate to new regulations and conditions. 


\section{Methodology}

In this chapter, I describe how the study has been carried out. I start by outlining some points of departure - how the methodology corresponds with the phenomenon of teacher identity and the theoritical framework. Then, I continue with the choices and the procedures made in regard to data collection and analysis. Finally, I discuss quality aspects of the study, bring up ethical considerations, and reflect on the research process. When relevant, I mention the specific features of each substudy. Table 1 gives an overview of the research methodology of this thesis.

As Table 1 illustrates, the empirical material used in the individual substudies differed. The first article is mainly built on observations, which implies that I can say something about the teachers' actions, which is the focus of the first research question. The other three studies, which are based on interviews, rather seek to explore the teachers' experiences and how they make sense of these and themselves. These articles focus on the teachers in their different capacities of LESLLA teachers, bilingual immigrant teachers and teachers in the fields of second language education for adults, which means that the articles complement each other in the striving to understand the complex professional LESLLA teacher identity. 
Table 1: The studies and their overall methodological features

\begin{tabular}{|c|c|c|c|}
\hline $\begin{array}{l}\text { Overall research } \\
\text { question }\end{array}$ & Type of data & $\begin{array}{l}\text { Research } \\
\text { participants }\end{array}$ & $\begin{array}{l}\text { Type of } \\
\text { analysis }\end{array}$ \\
\hline $\begin{array}{l}\text { Study } 1 \text { : What are } \\
\text { the significant } \\
\text { teaching actions } \\
\text { of LESLLA } \\
\text { teachers and what } \\
\text { are the } \\
\text { conceptions } \\
\text { behind these } \\
\text { actions? }\end{array}$ & $\begin{array}{l}\text { Field notes from } 86 \text { hours } \\
\text { of lesson observations and } \\
\text { interview answers } \\
\text { regarding the teachers' } \\
\text { actions. } \\
\text { The data is treated as a } \\
\text { retrospective construction } \\
\text { of the teachers' actual } \\
\text { actions and ideas. }\end{array}$ & $\begin{array}{l}\text { Nine LESLLA } \\
\text { teachers in three } \\
\text { different schools: } \\
\text { a private SFI } \\
\text { provider, a } \\
\text { municipality } \\
\text { school and a folk } \\
\text { high school }\end{array}$ & $\begin{array}{l}\text { Thematic } \\
\text { analysis } \\
\text { informed } \\
\text { by } \\
\text { abductive } \\
\text { reasoning }\end{array}$ \\
\hline $\begin{array}{l}\text { Study } 2: \text { How is } \\
\text { the professional } \\
\text { teacher identity } \\
\text { formed in the } \\
\text { encounter with } \\
\text { the LESLLA } \\
\text { teaching practice? }\end{array}$ & $\begin{array}{l}\text { Semi-structured interviews } \\
\text { beginning with the } \\
\text { participants' story. } \\
\text { The data is treated as a } \\
\text { retrospective construction } \\
\text { of the teachers' actual } \\
\text { experiences. }\end{array}$ & $\begin{array}{l}\text { Nine LESLLA } \\
\text { teachers with } \\
\text { former } \\
\text { experiences of } \\
\text { teaching in other } \\
\text { contexts, working } \\
\text { in two schools: a } \\
\text { municipality } \\
\text { school and a folk } \\
\text { high school }\end{array}$ & $\begin{array}{l}\text { Thematic } \\
\text { analysis } \\
\text { informed } \\
\text { by } \\
\text { abductive } \\
\text { reasoning }\end{array}$ \\
\hline $\begin{array}{l}\text { Study 3:How do } \\
\text { bilingual } \\
\text { immigrant } \\
\text { teachers in the } \\
\text { field of LESLLA } \\
\text { teaching } \\
\text { construct } \\
\text { professional } \\
\text { identity? }\end{array}$ & $\begin{array}{l}\text { Semi-structured interviews } \\
\text { beginning with the } \\
\text { participants' story. } \\
\text { The data is treated as a } \\
\text { retrospective construction } \\
\text { of the teachers' actual } \\
\text { experiences and as } \\
\text { constructions of teachers' } \\
\text { identity. }\end{array}$ & $\begin{array}{l}\text { Seven LESLLA } \\
\text { teachers who used } \\
\text { the students' } \\
\text { mother tongue as } \\
\text { a language of } \\
\text { instruction, } \\
\text { working in three } \\
\text { schools: a private } \\
\text { SFI provider, a } \\
\text { municipality } \\
\text { school and a folk } \\
\text { high school }\end{array}$ & $\begin{array}{l}\text { Thematic } \\
\text { analysis } \\
\text { informed } \\
\text { by } \\
\text { abductive } \\
\text { reasoning }\end{array}$ \\
\hline $\begin{array}{l}\text { Study 4: What do } \\
\text { changes in the } \\
\text { overall field of } \\
\text { second language } \\
\text { education for } \\
\text { adults mean for } \\
\text { the LESLLA } \\
\text { teacher's } \\
\text { professional } \\
\text { identity? }\end{array}$ & $\begin{array}{l}\text { Semi-structured interviews } \\
\text { beginning with the } \\
\text { participants' story. } \\
\text { The data is treated as a } \\
\text { retrospective } \\
\text { constructionof the } \\
\text { teachers' actual } \\
\text { experiences and as } \\
\text { constructions of teachers' } \\
\text { identity. }\end{array}$ & $\begin{array}{l}13 \text { LESLLA } \\
\text { teachers in four } \\
\text { schools: a private } \\
\text { SFI provider, two } \\
\text { municipality } \\
\text { schools and a folk } \\
\text { high school }\end{array}$ & $\begin{array}{l}\text { Thematic } \\
\text { analysis } \\
\text { informed } \\
\text { by an } \\
\text { inductive } \\
\text { approach }\end{array}$ \\
\hline
\end{tabular}




\section{Points of departure}

Whereas the SFI teacher profession, for example, is a publicly acknowledged social convention supported by laws and regulations, the LESLLA teacher profession is more implicit. Officially, there is no established group of professionals called LESLLA teachers in Sweden. One is employed as an SFI teacher or a mother tongue teacher, and one may define oneself as a teacher in study track 1, a teacher of learners with little previous education, or a teacher of initial literacy ('alpha teacher'). The term "LESLLA teacher" is primarily used by the international research community and it is not clear how much intersubjectivity the term holds. Besides, the meaning of the LESLLA teacher identity is a matter of the overall national educational context of adult educators and second language teachers, and it is situated in the different local contexts of the school practices.

The theoretical starting-point - situated learning - questions the idea that a social phenomenon, such as professional teacher identity, can be understood from either a complete individual or a collective perspective. Even if individuals construct their identities, learning, knowing and thinking are about relationships between people engaging in activities, and in turn these are linked to a socially and culturally constructed world (Lave, 1991, p. 67, 76). As a consequence, the explanations of LESLLA teacher identity that this thesis offers recognize a process of negotiation within the research participants, at the same time as it sees how this is intertwined with particular social contexts. Such an outlook has guided my interpretations.

\section{Research settings and participants}

Three schools were initially selected for data collection. To get a sample of teachers working in the various conditions that SFI education implies, the selection was based on the idea of collecting data in a variety of schools. Thus, one criterion was that they should be run by different organisers: one municipality, one private company and one folk high school. It was considered important to include a folk high school since they have some freedom from the ordinary regulations of the SFI system. 
Moreover, the schools had different geographical locations. One operated in a city where there were no other SFI opportunities for LESLLA learners, whereas the others had to compete with other organizers to be awarded an SFI contract and/or to recruit students. The schools were of different sizes. At the time of the observations, the total number of students in each school ranged from 275 to 1300. One school offered solely SFI courses, whereas the other two also offered other programmes. Two of the schools stressed the role of mother tongue teaching and employed both SFI teachers and mother tongue teachers. The third operated in the same way as the majority of SFI schools, with Swedish as the only formal language of instruction. The benefit of selecting different kinds of schools was that more of the diverse conditions that LESLLA teachers in Sweden face in their work could be included.

Later in the research process, a teacher from a fourth school was included to increase the data for the third research question how bilingual immigrant teachers in LESLLA teaching constructed professional identity. To recruit such a teacher to the study, a school was chosen that offered mother tongue teaching. This fourth school was run by a municipality, which was in charge of some of the SFI education and outsourced the rest.

In three of the four cases, I made use of contacts with people well-known in the field of LESLLA and/or SFI teaching to gain access to the schools. When I contacted the principals, who passed my enquiry on to the teachers, I mentioned that these people had recommended me to contact the school. In the additional case, I made contact with the school through a teacher in an internet forum for LESLLA teaching. After conducting a pilot interview with her, I was introduced to her colleagues, who also came to be my research participants. In all but the fourth school, from which I only sought one additional teacher, I was interested to recruit as many research participants as possible.

Altogether, the study is built on the direct participation of 19 teachers. An overview of them is given in Table 2 (Appendix E). They all taught on study track 1, i.e. having students with little or no formal previous education at the A and/or B level. The teachers were employed as mother tongue teachers or SFI teachers. Even if the number of mother tongue teachers is considerably lower that the number of the SFI teachers, they also function as LESLLA teachers. 
At the beginning of the research process, the criterion of selection was that the teachers were to be involved in initial literacy teaching. Due to other functions of the LESLLA teachers, however, this criterion was broadened to include all who taught emergent readers on study track 1 . Successively, I started to use the term "LESLLA teacher" instead of "literacy teacher". The former captures a fuller understanding of the profession, since it includes the aspects of the second language teaching and learning, and the fact that the learners had no, or little, previous schooling.

Among the research participants there were three men and 16 women. Female teachers are highly over represented in SFI, but a little less so in mother tongue teaching, at least in the schools where I conducted the observations and the interviews. The age of the teachers in the study ranged from the late 20 s to a little over $65-$ the age of retirement in Sweden. All but one had experienced teaching in other educational contexts before they began to work as LESLLA teachers, the majority in primary school. All but a two held a teaching degree, and everyone had studied at the university. Seven of the teachers had started to learn Swedish themselves when they moved to Sweden as adults or teenagers.

The LESLLA teachers were the main research participants. However, their students and colleagues contributed indirectly to the data, since the teachers did not carry out their profession in a vacuum, but in interactions with others. Also, a non-recorded, semistructured contextualized interview with the principals of the first three schools was carried out (eight computer-printed A4 sheets of paper in total) and included in the data (see Appendix D). The purpose was to obtain the perspective of a principal on initial literacy teaching and the history of the schools' LESLLA activities. These interviews served to increase the understanding of the school communities of which the teachers were members.

\section{Observations}

The first article of the thesis, which deals with the significant teaching actions of LESLLA teachers and the conceptions behind them, rests on data informed by ethnography. This is seen in how I, in field visits to schools, through regular participant observations 
and by asking direct questions, sought to understand the work of a LESLLA teacher and, in this sense, the culture of LESLLA teaching. I have studied people's actions in and accounts of everyday contexts (see Hammersley \& Atkinson, 2007). The certain influence of ethnography has its advantages. It gives an opportunity to the researcher to observe social patterns and interplays by her/himself and to use different types of data. Apart from observing the behaviour of others, one can make use of such aspects as conversations and more formal interviews with the participants and, in that sense, obtain rich data (Hammersley \& Atkinson, 2007). Also, since this thesis concentrates on the highly dynamic process of identity development, it made sense to obtain inspiration from an approach that concentrates on actions and interactions. Ethnographical data collection methods are particularly relevant when analysing, for example, the transition process from one practice to another and the effect of that transition (see Handley, Clark, Fincham, \& Sturdy 2007, p. 14).

About 86 hours of observation of lessons and other types of school activity (for example meetings, informal teacher conversations and conversations between the teachers and me) were distributed over 15 days. The work of 12 particular teachers forms the basis of the observational data, but many other teachers were observed indirectly in meetings and general conversations with the teacher I was currently shadowing. For logistic reasons, the visits to two of the schools took place on five consecutive days, whereas I made observations in the third school on five separate days over a five-month period. Most time was spent on observations of lessons, but the observations also included planning meetings, time spent in the work room for individual planning, and spontaneous collaboration between colleagues, in-service training sessions and break times. Field notes, which primarily focused on the teachers' actions and the contexts in which these occurred, were taken throughout the visits and an observation guide (see Appendix A) with some focal points, helped to maintain the focus (see Hammersley \& Atkinson, 2007, p. 142). In addition, I also observed two lessons, conducted by the teacher from the fourth school. But since the first article was already completed by then, these observations were used only to contextualize the interview. 
The students in the observed lessons aged from about 20 to 60 years. Most were women and a majority were refugees who had been less than two years in Sweden. The mother tongue of the students was mixed, but the dominant ones were Arabic, PashtoDari and Somali. The number of students in each lesson ranged from four to 30: it was in most cases about 12.

When the opportunity was given, either directly after the lesson or later as part of an interview, I raised questions of some significant teacher actions I had seen or, alternatively, I let the teachers respond to my interpretation of these. For example, I asked the reason that a teacher made use of a memory game in her class. Through such questions I could better understand the teachers' ideas behind a certain action and verify my understanding of it. This approach provided me with data that I could not get from observations and thus, ensured that I acquired a more holistic view.

Generally, while doing the fieldwork, I took the stance of a partly participating observer. This meant that I took part in the social interplay, but did not participate in the specific activities of the research participants (see Fangen, 2005, p. 141). However, the level of my participation differed somewhat, depending on how much the teachers wanted me to be involved and what I considered to be the best way to draw as little attention as possible to myself. For example, I often joined in, in the physical exercises of a lesson, when everyone was to stand and make different bodily movements. This involvement, I judged, created more trust for the teachers and the students, than if I had been distantly observing.

At the end of each day of observations, or in some cases, on the following day, I went through the freshly taken field notes. Things were clarified, adjusted and elaborated on. Together, the field notes from the observations constitute 95 computer-printed A4 sheets of paper.

\section{Semi-structured interviews, beginning with the telling of a story}

In addition to the observations, the informal conversations and the follow-up questions, data collected through semi-structured interviews played a significant role in the study. This was especially 
the case for Articles II-IV, which explored the LESLLA teachers' experiences and how they made sense of themselves in regard to these. In total, the thesis is built on face-to-face interviews with 17 teachers, together containing a little over 14 hours of audiorecorded material, i.e. 194 transcribed A4 sheets of paper. Before the data collection, I conducted pilot interviews with two teachers in two schools. One of these was later included in the overall data, since I saw that it contained data that was relevant for the fourth article. However, the intention with the pilot interviews was to try out questions for the interview guide and obtain a greater understanding of the LESLLA teaching field.

Semi-structured interviews are characterised by a number of issues that are to be discussed. However, they do not have to be treated in a certain order; they can be formulated differently; and questions that are not included in the pre-planned interview guide can be added if the interviewer wants to follow up something that the respondent has brought up (Fylan, 2005, pp. 65-66). This type of interview was suitable for the work presented here, since the main focus of the study, i.e. the professional identity of LESLLA teachers, was clear before the data was collected, and since I wanted the respondents to talk relatively freely about their experiences. Also, semi-structured interviews are useful when one seeks descriptions of the world as the respondents experience it (Brinkmann, 2014, p. 288).

The use of semi-structured interviews implied that, in spite of the use of an interview guide to ensure that all areas were covered (Appendix B), the questions were not exactly the same in every interview I conducted. Each interview situation was unique, and I refined my questions and my interview technique as the study progressed. To some extent, the questions and the order of them differed. One advantage of this freedom was that I could add a question connected to a respondent's current line of reasoning. This may have helped them to develop their stories and answers.

I chose to let all interviews with the teachers begin with a rather open question. I asked the participants if they could tell me the story of how they had come to work with LESLLA learners and developed professionally in this field. This question gave the teachers some freedom. For example, they could choose where to start. Some began when they were children and others when they 
started to work as LESLLA teachers. I used the word "tell" deliberately, since this word is generally considered to stimulate respondents to create a story (see Hydén, 2008, p. 115, 125). A story can say something of the identity of the teller. It can be told to illustrate one's membership in a community, to reflect, for example, a membership that corresponds to essential functions in the shared practice (Lave \& Wenger, 1991, p. 109). Moreover, stories say something about the teller's past. The ways in which workers interact with their current workplace concern their personal learning histories (Billett, 2004, p. 121).

When the story had been told, and sometimes during the story-telling, questions were raised to cause the teller to clarify, continue, and/or deepen the story (see Hydén, 2008, p. 125). Later on, I asked questions to cover the issues that had not been brought up in the story, but were essential for the understanding of teachers' trajectories into the communities of LESLLA teaching, their working environment/conditions and their view of the profession. In this sense, the interviews gradually transformed from being stories mainly driven by the respondent to an interview driven by me as researcher.

\section{Reflections on conditions influencing the interviews}

Since I used a semi-structured interview and not a structured one (see Brinkmann, 2014, p. 286), I was free to ask spontaneous questions about something the respondent had said, in order to obtain richer data of some issue. An example of this can be seen in the interview with Agnes. When she answered my question of how the work team would probably be in a few years' time, she mentioned that the principal wished to split it up, since large teams are not so easy to handle, and the other work teams in the school were smaller. This led me to ask: "When you say that you're not easy to handle, what are you referring to?" and this question generated much information of how she viewed herself and her work team in regard to the students and the other teachers at the school. This example can also be used as an illustration of how an interview is a co-construction between the respondent and the interviewer (see Hydén, 2008, p. 113; Kvale \& Brinkmann, 2009, p. $65)$. I asked the question and in this sense, I guided the dialogue, at 
the same time as my question was a response to what the respondent said.

However, the co-construction is not necessarily symmetrical. The researcher's objectives, which have initiated the interview and set its framework, are steering its focus. Still, the respondents are not without an agenda themselves (Hillier \& Diluzio, 2004, pp. 57). In this study, for example, some of the research participants took the opportunity to promote mother tongue teaching or to highlight the importance of initial literacy teaching. When listening to the teachers' arguments, it was difficult to remain neutral and some of the ideas developed in the third article, which targets bilingual teachers, came, partly, as a result of this.

The interviews depended on other circumstances, too. The time assigned for an interview was an important factor. Most interviews lasted about an hour, but in a few cases we had only about 30 minutes, squeezed in between the different assignments of the teachers. When there was little time, it could be stressful for them, and/or me, who had some insight into how busy they were and did not wish to take up too much of their time. Generally, though, the teachers, when they started to talk did not appear to be stressed. We talked about the amount of time we had for the interview in advance, and I made sure that the time limit was kept. In two cases, I became stressed myself. In the first of them, the teacher had previously refused to be interviewed. She then said that she was too stressed to cope with it during the week I was doing the field visit to her school. Later that week, she changed her mind but continued to point out how little time she had. This made me conduct the interview as rapidly as possible. However, once the interview was well under way, it became clear that she was not in a hurry. The reason that she first had declined to participate in the interview was to signal to the principal that there was too much to do. In the second case, there was a misunderstanding of the time we were to meet for the interview and I turned up an hour later than the teacher expected. She was not happy about it, and we had less time for the interview.

In addition to the factors outlined above, structural issues such as gender, age and ethnicity influence the relationship between the respondent and the interviewer. With a positive outlook on symmetry (see Vincent \& Warren, 2001, pp. 43-44), it may have 
been an advantage that I, like the majority of the teachers, am female. Also, in order to create a greater sense of symmetry, I pointed out that I had a past as a teacher in Swedish as a second language in an adult educational setting myself, if not in SFI and initial literacy teaching.

The issue of ethnicity also deserves attention. Although it is a structure that generally affects the relationship between an interviewer and a respondent (Vincent \& Warren, 2001, p. 41), it may be more obvious in the two cases in which the respondents used my appearance or name, Helena, to illustrate a 'native speaker Swedish teacher'. An example of the former is following transcript: "When I come to this country, I look at you as an SFI teacher. You are blond. You have blue eyes. You are fair, so you are Swedish. You are Sweden for me". Either the teacher was basing this on her conception of what native Swedish people commonly look like, or it shows how I, in her eyes, came to represent by my appearance 'Swedish' ethnicity. Concerning the use of my name, there were other teachers who used it, but not to illustrate a native speaker. For example, it was used when giving an idea of how a text for students to read was made up by real persons: "My name is Helena. I'm married. I've got eight children".

The closeness of the respondent-researcher relationship depends on other factors than structural factors. The personalities of the interviewer and the interviewee also play a role (see Vincent \& Warren, 2001, p. 44). Another factor that played a part was how acquainted the respondents and I were with each other when the interview took place. In the school to which I had the opportunity to return, I became acquainted with most teachers before the interviews. This contrasts to the situation in the first school I visited (apart from the pilot interviews). There, I was to carry out an interview on the very first morning of my arrival. Most likely, this condition influenced the possibility to build trust. My estimation is that I, in cases when I already had a relationship with the teachers, to a greater extent was considered to be on their side. In other cases, the teacher had a more hesitant attitude and did not seem to know where to place me. However, this may not just be related to how acquainted we were, but also to that I successively became more confident in my role as a researcher. In any case, it may be an advantage to be regarded as an outsider. Among other things, it can 
imply that the respondents strive to explain things they would otherwise take for granted that one knew about (Vincent \& Warren, 2001, p. 44).

\section{The analysis processes}

The analysis began during data collection. Since questions that could be used to shed light onto what it meant being and becoming a LESLLA teacher were formulated, the analysis was considered when designing the study (see Kvale \& Brinkmann, 2009. p. 147). Depending on their aims and research questions, there were varieties in regarding the data and/or the analysis of each substudy. These differences are discussed in this section, where an account of the thesis' overall analysis process is given.

\section{Transcribing interviews and demarcating each study}

A more focused analysis began when transcribing the speech to printed text. While doing this, I reflected on how what the teachers had said was related to the research phenomenon of professional teacher identity.

Since there is no consensus about how to transcribe an interview, and since there are advantages and disadvantages with different approaches, the way of transcribing was based on my opinion of what best suited my research purposes (see Kvale \& Brinkmann, 2009, p. 197; Karlsson, 2002, p. 15). As the content, rather than the form, was the focus of the study, I avoided phonetic spelling and chose to mainly use written language rather than oral. For example, I wrote the formal Swedish "de" (they) instead of the colloquial "dom" (which more accurately reflects oral use). But at the same time, I wanted to transcribe in a way that preserved the language of the respondents and this made me keep the word order, reiterations of words, fillers, and grammatical divergences.

After the transcription of each interview, I sent e-mail to all teachers but one (for whom I did not succeed in obtaining an adequate e-mail address) with the transcript and a request to comment on if there was anything in the interview that they thought was misleading in terms of how they view themselves as teachers, or anything they wished to clarify. Only two participants out of the 
19 gave feedback on the material. They made no adjustments, but confirmed the picture.

The set of data for each substudy is built on its aims and research question. If a transcript referred to these, it was included as data. In the first article, where my purpose was to explore the teaching practice of the teachers in regard to the learners, I selected relevant observations as a foundation for the analysis. I used the ones that included lessons that taught some kind of literacy activities to catch the particular nature of the teaching. This could help to answer the questions of what the significant actions of the teachers' teaching practice were, and how the teachers responded to the learners' actions. In addition, I also made use of teachers' answers to questions directed towards some of their actions. These shed light on how the teachers' actions were related to their conceptions of the learners.

In the three other articles, I was interested in the teachers' experiences and the meaning that they ascribed to them. Thus, it was adequate to use interview data. In the second study, the interviews with teachers who had been employed as other types of teacher before being introduced to the LESLLA teaching were useful. Additionally, for this study, I chose interviews from two schools only. By doing so, I could give more space to the current contexts and the teachers' personal trajectory. In the third article, where I focused on teachers using the students' mother tongue as a tool for instruction, I left out the interviews with the other teachers, which means that one school had to be excluded. Also, I conducted an interview with a teacher from a fourth school. For the fourth article, in line with the inductive approach, I based the dataset on a certain analytic interest present in all data items (see Braun \& Clarke, 2006, p. 6). It meant that I, after discovering that 'teacher identity during the process of change' was a common theme, carefully went through all interview transcripts and narrowed down the data to those 13 who had said something about this topic.

\section{Analysing the data}

I chose thematic analysis to make sense of the data. In short, this method identifies, examines and presents themes in the data. It can be used to analyse different types of data, for example field notes 
and interview transcripts, and it can be combined with different types of theoretical perspectives. In that sense, it is a very flexible approach. However, one disadvantage of thematic analysis is that it does not allow the researcher to keep the focus on contradictions and continuity throughout the account of an individual interview in the way that a narrative approach does. This introduces a risk that useful information is omitted (Braun \& Clarke, 2006, pp. 27-28). However, I have included some examples in the articles of how the local school context or the specific biography of an individual teacher informs the interpretation of a certain data extract.

The interpretation in thematic analysis can be either semantic or latent, depending on whether it is conducted from a realist/essentialist perspective or from a constructive one. In other words, it depends on whether the meaning and experience of the research participants are what they say, or if they are something beyond it, and, thus also, if the experience and meaning are something individual or if they are socially produced and reproduced (Braun \& Clarke, 2006, pp. 13-14). Since I applied a socio-cultural theory of learning and took the perspective of the research participants, I regard the data as a construction. Nonetheless, it is perceived differently, depending on the purpose of each substudy. In the first and second studies, the aim was to explore the teaching practice of the teachers in regard to the learners (Article I), or to explore how the professional identity of experienced teachers is formed when they begin to work in the LESLLA field of practice (Article II). Such aims imply that the data reflect actual events and experiences, although subjectively reconstructed by the interviewee and me. In the third and the fourth studies, on the other hand, the data were looked upon as both reconstructed experiences and meaning, and as constructions of the teachers' identity. This outlook is more in line with the aims of exploring the construction of professional identities of bilingual immigrant teachers in the field of LESLLA teaching (Article III) and what changes in the overall field of adult immigrant education mean for teachers' professional identity (Article IV). Moreover, in line with thematic analysis, I have focused on what the teachers said and not on the language they have used or the functions of these formulations (see Braun \& Clarke, 2006, pp. 27-28).

Even if the analysis process started when collecting the data, 
the main part of the analysis was carried out later. Generally, the analysis process followed five different stages: First, I familiarized myself with the data, something that included arranging the field notes and the transcriptions of the interviews (see Braun \& Clarke, 2006, pp. 16-17). The second stage was characterised by the process of initial coding, during which I went through the data and selected the parts that were of relevance for my research questions and tried to make sense of what they were about by coding them. This resulted in a number of different codes. In the following, third, step, I searched for potential themes emerging from these initial codes, and in the fourth step I reviewed these themes (see Braun \& Clarke, 2006, pp. 18-21). Generally, it was necessary to return to some parts of the data to verify some themes. During these two latter stages, in which I discovered new themes and re-categorized subthemes, I worked more actively to understand the themes with the support of the theoretical framework of each substudy and to forge different subthemes into one. For example, an earlier version of the third substudy reflects more general themes than a later version. Significantly, the themes and subthemes of the latter version are also more theoretically loaded.

When conducting steps 2-4 of the analysis process, I made use of the NVivo software 10.2.0 and 10.2.1. The field notes and interview transcripts were imported into the NVivo program, which made it easy to gain an overview of different categories and their hierarchical relationships with each other. For example, it was useful when making a link between the codes, the themes and the data items, and when I was to check the data items in which a certain word was used.

Despite having theoretical concepts from situated learning theory, and for Article III also notions from Bourdieu's field theory, in mind, the analysis process was mainly empirically driven. For the first three articles, it came close to abduction - a process of reasoning, which takes its departure in how social actors describe their lives, and aims at describing their social life scientifically. First, it concerns describing the activities and meanings of people, which should be followed by developing themes and concepts that support an understanding or an explanation of the phenomenon studied (Blaikie, 2004, p. 1). This approach helped me to uncover the practices and the beliefs that lay behind the teacher's actions, 
experiences and understandings - the mutual, but tacit, knowledge that is used, adjusted, produced and reproduced in interaction. This way of doing analysis implies that I could not only apply already existing theoretical concepts to the data but also generate new types of explanation (see Blaikie, 2004, p. 1). The analysis of the fourth study, on the other hand, was much more inductive. The ideas behind both the third and the fourth articles came from patterns that emerged in the data, but in the latter case, I did not make use of any theoretical concept until much later in the process. Besides, in the fourth study, I did not have a ready-made aim or any previously formulated research questions when starting to conducting the analysis. Instead, I began with the general point of departure of looking at the relationship between the teachers' identity and workrelated changes.

During the fifth stage of the analysis I refined my themes to ensure that they did not promise more than they could deliver. I also formulated the themes in words, and described them explicitly The latter involved me working to make each theme, and the whole presentation of the findings, a coherent and accessible story (see Braun \& Clarke, 2006, p. 22). During this stage, I had to pay attention to which quotations could best illustrate the themes. Moreover, I needed to consider how these quotations could be translated from Swedish into English. The quotations were chosen on the basis of their sententious character - the ones with relatively few words that caught the identified themes were selected. In the translation, caution was taken to stay close to the original meaning, but in the cases where grammar and word of order, etc., differed from the standard language, I made changes to facilitate the reader's understanding. The reason was to not draw attention from what the respondents intended to say.

\section{Quality aspects}

To ensure that this thesis fulfils the required academic standards, several aspects have been considered. There is no consensus of the quality aspects that should apply in qualitative research. Two quantitative criteria that are often used are reliability, which ensures that it is possible to reproduce the results of a study, and validity, 
which ensures that one measures what one aims to measure and that the results reflect reality (Brink, 1993). However, other criteria are considered to reflect more accurately the qualitative nature of research (Lincoln \& Guba, 1985, p. 219), and I use these to illustrate how I have striven to ensure quality.

The first issue, dependability, corresponds to reliability, and is related to the overall quality of the study and how the conclusions have been reached. A dependable study is one in which peers judge that proper procedures have been followed (Lincoln \& Guba, 1985, p. 219, 318). The dependability criterion can be combined with what Larsson (2005, pp. 18-20) calls "perspective consciousness". By giving an account of previous research related to the phenomenon studied in this thesis, and by presenting the theoretical perspective and the methodology and methods applied in it, it has been my intention to show the points of departure and preunderstandings I had. Moreover, Larsson (2005, pp. 20-21) suggests the criterion of "internal consistency" - qualities in the presentation as a whole. A study has internal consistency if the research questions, the phenomena, the underlying perspectives, the methods, and approach used during analysis are harmonious. By frequent discussions with my supervisors and other researchers in seminars and conferences, the connections between the research question, theory and methods have been considered. In addition, I have tried to facilitate the maintenance of this relationship by letting each article primarily represent one research question.

A second quality criterion is credibility. A study is credible if there is sufficient support in the data for the findings and the conclusions to be accepted as trustworthy (Lincoln \& Guba, 1985, p. 301). The use of two different research methods, observations and interviews, served to triangulate the results (Larsson, 2005, p. 29). The fact that I made observations implied that I gained a greater familiarity with the context, and this helped me to analyse the interviews. This analysis then came to inform the observations to some extent. For example, in the first article, I explicitly verified my interpretations of the observations of the teachers' behaviour by asking them about it. The triangulation served to strengthen the empirical anchorage - the correspondence between reality and interpretation (see Larsson, 2005, pp. 28-29).

The third aspect, transferability, concerns whether the 
findings can be applied in other contexts (Lincoln \& Guba, 1985, p. 316). According to Larsson (2009), there are different ways of reasoning when it comes to generalization. In qualitative research when generalization is essential, there are three ways to claim that the study is transferable: by maximum variation, context similarity, or recognition of patterns in common. In spite of the samples being taken from different types of school, and including interviews with teachers with different backgrounds and working under different conditions, I judged the sample too small to claim generalization through maximum variation. Generalization based on context similarity, i.e. that the findings of the study can be applied in all contexts that closely resemble the context of the study, is more suitable for studies with much contextual data, as is so in, for example, case studies more than it is so in interview studies (see Larsson, 2009, pp. 7-9). I do, however, believe that this study is transferable, since the results reflect to a great extent the results of other studies, which relate to LESLLA teaching.

I also claim transferability through the recognition of patterns in common. This means that part of the research can be applied to other contexts when someone uses its interpretations to make sense of another context or phenomenon (see Larsson, 2009, pp. 9-11). Thus, I have been concerned about the richness of meaning (see Larsson, 2005, p. 23), by including many quotations from the interviews and excerpts from the field notes. These reflect the voices of the participants, and display the basis of my interpretations. The quotations help the reader to compare the context of the study with other situations, and see what similarities there are.

The fourth quality aspect, confirmability, requires that the researcher show that s/he has not intentionally swayed the study with personal theoretical starting points or personal values. It is about the trustworthiness of the data, findings, interpretations and implications (Lincoln \& Guba, 1985, p. 318). By constantly reminding myself that my own ideas and pre-understandings influence my interpretations, I have striven to ensure confirmability. During the data collection, I made reflections, which included my own actions and conceptions, after each interview. I did this also during the analysis. Moreover, in the field notes, I wrote reflections in italics (to make them visible) of my interpretations of what I 
observed and of the role I played myself. An example is seen in following excerpt from a teacher's meeting in the third school.

The basket with reading glasses is empty. Where are they? This starts a discussion about where the glasses have gone and it generates a great deal of laughter. (Thus, the school has glasses for the students and the teachers' role is to serve the students with them.) The sum total of the discussion is that everyone who had taken glasses puts them back ... "Everyone is to look for cheap glasses," Agnes says - she will do it herself. (Consequently, one is a teacher not just in school, but also, for example, when going into town). "Now, the lost glasses will be a part of the research report," Rebecka says. (This shows that one is taking notice of my presence.)

The excerpt illustrates how I strove to keep track of my interpretations, by describing both what I observed and how I comprehended it. In addition, this piece from the field notes displays how my presence, as any person's attendance in a social research setting, influenced the participants. It was easier for me to blend in the lunchroom, where there were always other white, native Swedish-speaking women of my age, than in the classroom, but in all situations I did my best not to draw attention to myself. My presence, however, affected the teachers.

\section{Ethical considerations}

A further criterion that contributes to the quality of a study concerns its ethical values. Among other things, producing new knowledge is to be balanced against the protection of the research participants (Larsson, 2005, p. 22). For all substudies, I have followed the general principles of ethics in social research that have been established by the Swedish Research Council $(2011,2017)^{4}$. I have taken measures to ensure that the confidence given by participants is not abused. The research participants received information in

\footnotetext{
${ }^{4}$ Since no substantial changes has been made in the parts I refer to, I only bring up the most recent version in the reference list.
} 
advance of the purpose of the study and what their participation would involve. This was first e-mailed to a contact person in the school, who passed it on to the teachers. In two of the four cases, I subsequently gave the same information to all concerned staff, in a work team meeting or general staff meeting. In these meetings, I also gave the assurance that the study was to follow the research ethics of the Swedish Research Council. Ethical principles were brought up also during the introduction to each interview. Apart from presenting the study itself, I pointed out that participation was voluntarily, that the data were to be treated confidentially, for example by using pseudonyms instead of the participants' real names, and they would be used exclusively for research purposes. After that, the participants gave their consent. This procedure, and the opportunity later given to make adjustments to the interview transcript, ensured that the teachers were updated on what their participation entailed and made aware that they could withdraw from it at any time.

A somewhat more problematic ethical aspect is related to observation of the teachers' work. The teachers, who were the main participants, and the headmasters, approved of my observations. But it is questionable whether the students, whom I observed indirectly during the teaching, gave completely informed consent. Thomas and Pettitt (2017, pp. 279-280) state the importance of endeavouring that learners in second language education should understand what they agree to when they are part of research and I certainly strove to inform them. I presented myself, or was presented, in almost all classes I observed. (The lessons during which I was not introduced took place in a school where the doors were always open. I could join a class for a short period without giving advance notice, and then go to another one. Because of that, I sometimes arrived in the middle of the lesson, when the teacher and the learners were involved in certain activities.) In the mother tongue teachers' lessons, the students received this information in a language they spoke fluently, but in the other cases they received it in Swedish since my knowledge, and in many cases the teacher's knowledge of the mother tongue, was very limited. Due to these language gaps and the fact that research is an abstract phenomenon, the information was simplified to facilitate the learners' 
understanding. Thus, the main message was that I was there to look at the teacher.

According to Thomas and Pettitt (2017, p. 279), it is also important for a researcher to reflect on how the research could affect second langue (L2) learners negatively. Among other things, they point out that students may be stressed by publicly having to expose their performance. However, in the case of this study, the students' performance has not been in focus and, furthermore, I was working under the guiding principle of weighing the value of the research against the risks to which the research participants are exposed, such as intrusion into their integrity (Swedish Research Council, 2011, 2017). The activities I observed were mainly collective and I participated in some of them myself. I usually considered the response to the teacher from the whole group of learners' rather from a single student, and it is this behaviour I describe in the articles, I have not included transcripts from field notes that illustrate a single student in a particularly vulnerable position. Moreover, the fact that many of the students were used to school visitors may have meant that my presence did not create any additional stress for them. The learners understood that I was there to observe the teacher: many of them took me for an inspector who had come to evaluate the teaching. This prevented them from feeling that they had been put under a microscope.

\section{Reflections on the research process}

Writing a $\mathrm{PhD}$ dissertation involves a process of learning. It can be likened to a trajectory into an academic landscape, consisting of a number of different theoretical and methodological practices. However, just as the participants in this study were not blank slates, nor was I when I began this trajectory. One crucial preunderstanding was my own teacher background. I had worked as an educator in different contexts, among other things in adult and second language education in both formal settings and and in nonformal and thus I already had some ideas of what it meant to a teacher in different contexts. I was familiar with general teaching routines and, thus, I better could imagine what the teacher experienced. Moreover, since I identified myself professionally as a 
teacher, I could for example feel sympathy for the challenges the teachers met and tended to 'take their side' (emotionally if not verbally) when hearing about their struggles. To handle this, I constantly reminded myself of my role as researcher, and tried to respond in a neutral way. This process can be understood as a transfer from an imagined teacher community to a research community or landscape.

Another pre-understanding had been formed as I wrote my master's thesis about initial literacy teachers in Sudan. Among other things, that study showed that the literacy educators' main concern was the attendance of the participants. To encourage attendance, the teachers stressed caring and respect for the learners as well as the importance of teaching in a contextualised way, which made the learning meaningful (Colliander, 2012). Thus, an early idea in my $\mathrm{PhD}$ project was to explore the relationship between the educator and the learner. At the beginning of the research project, also, I focused very much on the teachers as literacy instructors, since this was the core of my master's thesis. Successively, however, I came to realise that it was more appropriate to deal with the teachers as LESLLA teachers, considering that they also were teachers of adults, immigrants and second language learners. It was not fruitful to distinguish the literacy aspect of the teacher when dealing with their identity in the Swedish setting.

Other perspectives developed during the research process. One thing that surprised me was that I could not see much difference in teaching the LESLLA learners depending on the type of school in which the teacher worked. In spite of individual teachers having different teaching styles, for example some used more digital tools than others, there was generally an accordance in how the lessons were set up.

Moreover, the focus of the articles developed during the research process. Whereas the first two articles concentrated on what was happening in the classroom and how the teacher was learning the profession, Articles III and IV came to link teacher identity to macro conditions such as language hegemony and societal change. The fourth article, in particular, served to situate teacher identity in a broader context. Furthermore, the research questions of the latter two articles were formulated more on the basis of what had been found in the data. 
Another change that occurred as the research progressed concerned my methodological choice. In the first part of the process, I strove to combine a narrative approach with my data and the situated learning theory. However, this turned out to be problematic. Among other things, I had rather short interviews, which did not contain an elaborate coherent story of professional development. What was important, moreover, was that the methodology of the narrative approach did not contribute to enhance what I wanted to do. 


\section{Summaries of the substudies}

This dissertation consists of four separate substudies. In this, chapter I will first point out how they relate to each other and then make a brief summary of each of them.

\section{The relationships between the substudies}

Since the overall aim of the thesis is to explore what it means to be a LESLLA teacher and develop as such, the substudies focus on different aspects of professional teacher identity. The theoretical perspective of situated learning is applied in all substudies. Even if different ideas from the theory are used in the different substudies, the idea that LESLLA teachers are members of multiple communities of practice forms the basis of the analysis.

The first study concentrates on the teacher identity from the LESLLA teachers' actions and the conceptions of the learners that lay behind these. As it has the teaching and learning practice in focus, the data consist of field notes from lesson observations and follow-up questions to the teachers. Also, unlike the other substudies, this study includes the aspect of literacy, since this is a significant part of the teaching practice. The second study is built on the teachers' accounts of their professional trajectories and work. Here, the teachers' actions are not what is essential, but their experiences as newcomers in the landscape of LESLLA teaching. Since this study focuses on the development of a teacher identity, an overall theme in it is learning. The third study treats how identity is constructed from the perspective of power. It is based on what the teachers told me about themselves in the interviews. It differs from the other articles in the sense that it solely deals with the bilingual LESLLA teachers and not with LESLLA teachers in general. The theme in fourth study, which also is based on data from the semistructured interviews with the teachers, is teacher identity in regard to change. This study is the most inductive, and it differs from the other substudies by its wider focus on the LESLLA teacher as a teacher of SFI and adult education. This article highlights, more 
than the others, that there are other factors than the individual or the local communities that play a role for the identity.

But in spite of the concentration on different aspects of teacher identity in each article, there are no sharp dividing lines between them. Actions, learning, and the construction of identity are intertwined issues, which are closely related to the external conditions.

\section{Article I: Actions and conceptions: exploring initial literacy teaching practice for adults}

Manuscript accepted in Journal of Language, Identity \& Education doi: 10.1080/15348458.2018.1465344

Helena Colliander, Song Ee Ahn \& Per Andersson

Department of Behavioural Science and Learning, Linköping University, Sweden

This first study gives a picture of initial literacy teaching practice in the LESLLA context. It sets out from the overall question of what the significant teaching actions of LESLLA teachers are and what conceptions lie behind these actions. Since the learners of LESLLA, unlike other participants in second language education for adults, are emergent readers, the study is linked to the body of research of initial literacy teaching. Previous research had shown that there are different views on what literacy is and, consequently, different perspectives on how literacy should be taught. Moreover, the study reflects LESLLA teaching as a complex activity, in which the teacher must consider many aspects of the learners' conditions. The analysis is primarily built on field notes from 16 lesson observations of nine female teachers in three different schools. In addition to these observations, data were collected by asking the teachers to comment on their actions, either more informally after the lesson or as part of a semi-structured interview.

The teaching is regarded to be intertwined with the learning. Together, these form a community of practice (Lave \& Wenger, 1991) in which the teacher and the students participate for the joint goal of the students' learning. Crucial in this process are also the concepts of artefacts and negotiation. 
The findings show that the lessons, in spite of their differences, follow a general pattern. There are four main activities that teachers carried out during them. First, they initiated and negotiated the lesson activities. These were: a) a teacher-controlled conversation at the beginning of the lessons, b) a teacher-led instruction either comprising themes with a certain vocabulary or initial literacy exercises, c) physical exercises, and d) tasks that the students' worked with on their own. Even if it was the teachers who introduced these activities, they let the students negotiate both the content and the methods. Secondly, the teachers strove to get the students to understand words and other symbols. By doing so, they made use of a variety of artefacts, for example visual and oral strategies, that considered the learners in their capacity of for example being second language learners, and/or emergent readers. The third type of action was to help the students to get around in society by bringing material from everyday life into the classroom and/or locating the lessons outside it. Fourthly, the teachers negotiated acceptable student behaviour. They tried to balance the students' different needs, as learners, parents and immigrants/refugees.

In the discussion, four specific features of the LESLLA teaching practice are highlighted. Firstly, it is clear that the teachers are free to decide which teaching and learning material they want to apply, and their choices signal a desire to connect the material to the everyday life of the students. Such material could facilitate the learning since it contextualizes it and makes it relevant. Also, it serves as a help for the students to navigate in society. The second and the third features - the use of a variety of artefacts and repetition - can be explained from the conception the teachers had of their students of being second language learners and emergent readers. The final, fourth feature, negotiation based on the different memberships of the students, involves a broader outlook on the students. It implies that learners are viewed as adults with experiences and responsibilities in their lives outside school, and as newcomers in the society, and therefore in need of guidance and care. The article discusses how the actions, and the conceptions that lay behind them, say something about the identity of the LESLLA teacher. They show how s/he constantly shifts between many different subidentities: being a teacher to learners with complex 
needs, being a caretaker of people in challenging situations, and being a bridge builder between the students and society.

\section{Article II: The experienced newcomer - The (trans)forming of professional teacher identity in a new landscape of practices}

Manuscript published online in Teaching and Teacher Education, doi: 10.1016/j.tate.2017.10.012

Helena Colliander

Department of Behavioural Science and Learning, Linköping University, Sweden

To teach low-educated adults in second language and initial literacy is different from other types of teaching. This second study is based on the question of how the professional identity of already experienced teachers is formed in the encounter with the LESLLA teaching practice. The research review illustrates professional teacher identity as a vast field, but with little written about the LESLLA teaching context.

The underlying perspective of the study is that learning means identity formation (Lave \& Wenger, 1991), and I apply the concepts of participatory practice to comprehend such a process (Billett, 2004, p. 109), community of practice and landscape of practices (Wenger-Trayner \& Wenger-Trayner, 2015). Semi-structured interviews have been conducted with nine teachers, focusing on how they became LESLLA teachers and developed as such.

The results show that even teachers with experience from teaching in other contexts find LESLLA teaching challenging. In the beginning of their LESLLA teacher career, they were not familiar with teaching such learners as emergent readers and adults, nor with using the mother tongue as a tool. Moreover, a lack of adequate teaching material meant that the teachers had to produce much of it themselves. Although they could situate previous experiences and abilities from former teaching jobs and from the personal sphere of life, the organised and non-organised opportunities for learning offered by the work communities in the 
professional landscape of practices were essential in their identity formation. Nonetheless, these opportunities were looked upon and acted on differently. First, the teachers' participation in them was more or less purposeful. In some cases, teachers could participate in them with the explicit goal of learning something, whereas in other situations they learned even if it was not intended. Secondly, the teachers' individual agency, implied that there were differences in the communities they engaged in, or imagined that they were members of. Thirdly, the teachers deployed individual strategies for learning within a collective pattern. The response to the learning opportunities was influenced by the teacher's biography.

The results show that there is a transformation of a professional teacher identity, rather than the formation of a new one. This is because the teacher situates the former experiences and abilities, which s/he recognizes as valid in the new practice. Further, there is diversity as well as unity in the communities that contribute to the teachers' learning. Some stress their former experience and abilities more than others and the significance of each community in the occupational landscape of LESLLA differs from teacher to teacher. Since all teachers are engaged in teaching, and since all other practices within the landscape are to support the community of practice, this community plays a central role for learning. But when it comes to the other communities, there is more diversity in what they mean for the professional identity formation. Lack of learning opportunities in the local school context may lead the teacher to look for possibilities for learning elsewhere, but $\mathrm{s} / \mathrm{he}$ can also do so if it is in line with how s/he defines her/himself.

It seems vital that the school provides many different learning opportunities for new LESLLA teachers. This may lead to the teacher finding opportunities that correspond to her/his biography and thus imply an increased understanding of LESLLA teaching practice. 


\section{Article III: Building bridges and strengthening positions: exploring the identity construction of immigrant bilingual teachers}

Manuscript published online in International Journal of Bilingual

Education and Bilingualism, doi: 10.1080/13670050.2017.1400516

Helena Colliander

Department of Behavioural Science and Learning, Linköping University, Sweden

In study III, I explore how a particular group among the LESLLA teachers, the immigrant bilingual teachers, construct professional identities in the stories of their teacher trajectory and work. Research covering this group of LESLLA teachers illustrates how social structures related to language hegemony influence their work conditions and shows that this, in turn, influences the teachers' professional self-concepts and their actions (Valenta, 2009; Ganuza $\&$ Hedman, 2015). However, few studies take bilingual immigrant teachers' perspectives in regard to their structural positions and this study seeks to narrow that gap.

To analyse the identity construction of immigrant bilingual teachers, I combine the notion of community of practice (Lave \& Wenger, 1991) with Bourdieu's concepts of field and capital (Bourdieu, 1998). The study is built on semi-structured interviews with seven bilingual teachers with an immigrant background, who work either as SFI teachers or mother tongue teachers within LESLLA. All teach with the students' mother tongue as a tool.

The findings reflect how the bilingual teachers constructed their professional identity from their relation to the students. In contrast to the students, they presented themselves as old-timers in the new Swedish-speaking and new citizen communities. They pictured themselves as bridge builders between the students' communities on the one hand, and the native-speaking teachers or Swedish society in general on the other. Occasionally, membership in both a student community and a teacher community could be problematical, since the teachers, in some situations, had to choose which community to align with. Furthermore, the bilingual teachers constructed their identity in regard to different types of teacher 
community: as LESLLA teachers, as bilingual teachers, and as qualified teachers. In this negotiation, institutional and embodied teaching capital were used. The local school communities in which the teachers engaged, generally, meant much for their professional identity construction. In these, the bilingual teachers gained access to a strong occupational position. This was due to the communities' positive attitudes to mother tongue-based teaching, which had been reproduced when the teachers learned from the participation with old-timers. To some extent, however, the teachers also negotiated their position in the school communities.

The discussion shows that the teacher's strong position in the local school community helps her/him to position her/himself in communities where $\mathrm{s} / \mathrm{he}$ imagined a membership. Consequently, membership in a local community appears to mean more for the teacher than the imagined ones. Moreover, the teacher's membership in one community has an impact on the relationship to other communities s/he belongs to. Aligning with a certain community may imply that one distances oneself from another. In any case, the findings indicate that a strong position in the occupational field of a LESLLA teacher is not granted solely by a strong position in the local school communities. It is also a matter of the language hegemony. The bilingual teacher must legitimize her/himself by acquiring additional capital through education, and by stressing the institutional and the embodied capital s/he already has. However, in LESLLA teaching the bilingual capital appears to have a greater value due to the nature of the learners. 


\section{Article IV: Being transformed and transforming oneself in a time of change: a study of teacher identity in second language education for adults}

Manuscript submitted for publication

\section{Helena Colliander}

Department of Behavioural Science and Learning, Linköping University, Sweden

The fourth article focuses on professional teacher identity in regard to changes in the field of adult education in general and in introductory second language education in particular. The aim is to explore what changes in the overall field of adult immigrant education mean for teachers' professional identity. In contrast to most studies on professional teacher identity and change, it does not focus on one particular reform, but on the overall situation of a teaching landscape where many changes are taking place.

The study is based on semi-structured interviews with 13 LESLLA teachers. In addition, non-recorded conversations with three principals and field notes of teachers' everyday work help to contextualize the interview data. The study applies the situated learning theory, with an emphasis on the concepts of alignment, agency, regime of competence and community and landscape of practices, to understand what changes imply for a teachers' identity. However, since this is a rather inductive study, the concepts were tried out and adapted later on in the analysis process.

The results show that changes on the macro level lead to changes in the teachers' work. The broader changes that the teachers talked about have been categorised as migration, marketization and streamlining, and digitalisation. All had implications for the teachers' actions. Some changes implied opportunities for the teachers to develop their teaching or to strengthen their position in professional communities, whereas others restricted them and caused stress. Moreover, the results highlight the actions the teachers took in response to the changes. For one thing, the teachers' ways of aligning to changes were 
closely related to what they meant for their learners and the teaching and learning practice. The teachers embraced changes that were seen to have a positive effect on these two issues and rejected those that did not. Besides, the teachers could negotiate a change after its implementation for the sake of the learners and teaching. Also, by speaking for their learners the teachers positioned themselves by emphasizing their competence, and their response could be connected to a collective agency, as well as an individual one.

From the results, three particular features are discussed. First, the teacher is transformed by the changes at the same time as s/he is actively transforming the communities s/he belongs to and her/himself in regard to them. The teacher is to submit to the changes, but s/he can, in parallel, be at the head of them or offer resistance to them. Secondly, a change is seen to be negotiated both in regard to a local school community and to one's individual teacher trajectory. In the local teacher community, there can be more or less of a collective agency. Thirdly, the LESLLA teacher competency is in the centre of the negotiation. Due to the characteristics of LESLLA students, the teacher needs other specific competency. Moreover, it is possible to understand the LESLLA teachers' claims of particular competencies in the light of the fact that they are one of many competing voices in SFI education and that there is a need for struggle to ensure that one's knowledge is recognized (see Wenger-Trayner \& Wenger-Trayner, 2015).

Since it is vital for the quality of the teaching that the teachers align to changes, it is important to consider their experience and competence when deciding on a change and/or when implementing it.

\section{Overall findings of the thesis}

The substudies have shown a number of things concerning LESLLA teacher identity. Since the research questions, primarily, are represented in one article each, I will not go through them, but instead present the overall empirical findings for each article.

First, LESLLA teachers construct professional identity in regard to the particular characteristics of the learners, i.e. that they 
are adult emergent readers and second language learners establishing themselves in a new society. This is seen in how the teachers' teaching actions were rooted in the conceptions they had of the learners. The teachers adjusted their actions to the learners' capacity of being second language learners, emergent readers, as well as adults and people with extensive social needs. Likewise, many of these learner attributes formed the basis of what the teachers wished to learn as newcomers in the field of LESLLA and motivated them to make use of different learning opportunities. For example, the fact that the learners were emergent readers was seen in the artefacts the teachers used in teaching, and this feature was a reason that experienced teachers felt insecure when new in the LESLLA teaching field.

Moreover, the teachers explicitly defined themselves in regard to their learners. The bilingual teachers did so by giving the picture of themselves as old-timers in the new Swedish-speaking and new citizen communities, and LESLLA teachers in general negotiated change by referring to the learners' needs. The teachers stood out as the ones who, in contrast to others, understood their learners.

Secondly, identity development is a never-ceasing process, with some periods particularly critical for learning when becoming a LESLLA teacher. The findings reflect how the teachers' learning evolved, especially when they were new to the LESLLA teaching practice. In that situation, they experienced a great need to learn, since many aspects of the teaching were unfamiliar to them. But the learning did not exclusively happen during this part of their career. Also when they were experienced in the landscape of LESLLA teaching, the teachers developed their understanding of the learners and found new ways of teaching. This happened not least when they, individually and collectively, negotiated changes coming from outside, but also more continuously in response to the learners' actions in the teaching and learning practice.

Thirdly, LESLLA teachers' becoming is a process that takes place in a number of different communities. The significances of these communities differ. The study displays an abundance of memberships in communities, which all contributed to the teacher identity. There are for example the local school communities like the teaching and learning practices, the work team and the whole 
school, and general communities of a more imaginary nature e.g. of SFI teachers, bilingual teachers and LESLLA teachers.

The community that appeared to be most crucial was the teaching and learning practice. This was not only a practice in which the teachers frequently acted in regard to the conception they had of the learners and where they developed much of their knowledge and skills of LESLLA teaching. It was also a practice to which the teachers often related when positioning themselves in regard to other groups and/or when aligning to changes. The significance of the teaching and learning practices can be explained by the fact that it is a community that the other LESLLA-related communities were to support. However, when it comes to the other communities to which the teachers belong, there was a variety in what they implied for teachers' identity. Whereas some data speak of the significance of the local work team, or the overall school, the communities of which the teachers imagined themselves to be members, such as the LESLLA teacher community and/or the bilingual teacher community, were highlighted by others. Moreover, the communities that the teacher belonged to outside the work domain, such as a family and/or a new citizen community, were seen to play a part for how they negotiated their experience of working.

The teachers' memberships in different professional communities could in some cases oppose each other. This occurred when the values and the actions of a certain community greatly differed from those of another, or when a teacher stressed her/his membership in a certain community and thus positioned her/himself towards another community.

Fourthly, teacher identity is formed and constructed in regard to power relationships in the professional communities and the fields to which the teachers belong. It evolved in regard to more overall power structures and the teachers' own power. A number of issues affected the LESLLA teachers' opportunities for learning and being acknowledged as professionals. It was a matter of national decisions concerning teacher qualifications, and the organisation of adult education and SFI. Behind these lay different perspectives on professionalisation, the language of instruction, the effectiveness of education, and the importance of digitalisation. In turn, these perspectives were related to societal transformations such as 
migration and changes in the labour market. Changes on the macro level could limit and/or enable teachers' actions, and in this sense, the teacher identity depended on societal forces.

Nonetheless, the teachers also possessed power. They were playing an active part in the formation of their professional identity. For example, they rather freely organized their teaching by choosing the lesson content and the methods in regard to their conceptions and the response of the learners. They aligned to changes in a way that was of benefit to their learners and teaching. Moreover, by describing how they actively took the opportunities for learning that were consistent with their agency and biographical background, and by positioning themselves as members of certain communities, the teachers constructed themselves as professionals with power. In this way the teachers claimed certain professional capital and presented themselves as competent professionals.

The access to the communities at the local school level played a central part for the teachers' position. That they were often treated as legitimate members meant that they experienced power within many of the communities in which they engaged. 


\section{Discussion}

The aim of this thesis is to explore what being and becoming a teacher of LESLLA learners means. The work presented here has analysed how the professional identity of LESLLA teachers can be understood from their memberships in different communities of practice. Here in the discussion, I will elaborate on this from the study's overall empirical results and in regard to my theoretical framework and previous research. I proceed to make some critical reflections on the thesis, before, finally stating the implications of it and giving some ideas for future research.

\section{Constructing identity in regard to the particular nature of the learners}

One of the study's overall findings - that the LESLLA teacher identity is constructed in regard to the particular nature of the learners' - can be further comprehended by considering the concept of regime of competence (see Wenger, 2010; Wenger-Trayner \& Wenger-Trayner, 2015). The study illustrates that there are competencies related to the learners that are valid in an overall imagined LESLLA teacher community. These are seen in the teacher's teaching actions and in the actions s/he says s/he has taken to learn or to respond to something. There are competences developed by participation in the teaching and learning practices, the work team and other school communities.

The core competence is to consider the learners' needs in teaching and adjust to these. Certainly, this is not something unique for the LESLLA teacher. Many studies bring up that the teachers act in regard to their learners (see e.g. Tsui, 2007; Buchanan, 2015). But what stands out in this case is the particular nature of the learners: that they are adults, emergent readers, second language learners, new citizens and often refugees at the same time. This implies other needs than if they were to be characterized only by their adulthood and/or by being second language learners. Moreover, the ability to teach initial literacy to adults, which is 
highly significant for the LESLLA teacher, is difficult to isolate from the other properties that characterize the learners.

In turn, this core competence implies two more specific competences, which are not primarily about teaching (although related to it). One of these is the ability to care for the learners. That caring is a valued competence is shown in many of the teacher's actions: how s/he balances the demands on learning with the awareness of how the learners' private domain can affect the learning, supporting the learners in personal matters and speaking on their behalf to safeguard the quality of the teaching and learning. The other specific competence is the ability to act as bridge builder between the learner and society. "Bridge builder" and "bridge building" are terms used to describe the particular function of the teacher who teaches with the mother tongue as a tool. S/he can be a bridge builder, since s/he is an old-timer in the new Swedishspeaking and new citizen communities in Sweden. Simultaneously, however, the native Swedish speaker LESLLA teacher also acts, and says that $\mathrm{s} / \mathrm{he}$ acts, in a bridge-building way. This is seen in how s/he facilitates the students' participation outside the teaching and learning community by bringing the everyday domain into the classroom and by taking the students to the societal domain in study visits. Also, outside the teaching, the teacher supports the learners by giving advice and information.

Research on adult and second-language educators brings up the importance of generic teaching skills (see Freeman \& Johnson, 1998; Wahlgren, 2016) and linguistic competence (Tarone \& Allwright, 2005). It is considered crucial to focus on these issues in the teacher training. Interestingly, however, the three competences that this study has identified as central for the LESLLA teacher' actions are rather specific, and are linked to the particular group of learners. It is possible that the reason for this is that the teachers had developed generic teaching skills already when they began their LESLLA teaching trajectory, and in many cases, they also had knowledge and skills of second-language teaching.

Even if teacher education can help the teacher to conceptualize teaching and learning, her/his professional learning, in line with Lave \& Wenger (1991), comes rather from participation in work practices, e.g in teaching and cooperating with old-timers among one's colleagues. It is in these ways that the teacher becomes 
familiar with the learners and learns to make use of the different artefacts of the LESLLA teaching and learning practice. Besides, since there are few opportunities for specific LESLLA teacher training within teacher education, the teacher has often no other choice than to rely on what s/he learns from the work practices.

\section{Becoming a LESLLA teacher is an ongoing process...}

The study illustrates that becoming a LESLLA teacher, indeed becoming any teacher - is an ongoing process. Even experineced teachers learn. Such a claim supports what many other studies have shown, that teacher identity is something dynamic (Beijaard, Meijer \& Verloop, 2004; Beauchamp \& Thomas, 2009). Situated learning has been criticized by pointing out that learning is not something that only newcomers experience (Fuller et al., 2005, p. 64). In agreement with this criticism, the findings of the thesis highlight that the learning process of a teacher intensifies not only when, for example, s/he is a novice in the profession (see Liu \& Fisher, 2006; Avalos, 2011; Kanno \& Stuart, 2011). Another critical period of learning is when an experienced teacher transfers from one type of teaching and educational system to another. If applying the landscape-of-practices metaphor (e.g. Wenger, 2010) on the latter, one can understand such a professional trajectory as a journey either within an overall teaching landscape between two types of teaching practices for example of the primary school and LESLLA, or as a journey between two different types of occupational landscape. With the focus I have on LESLLA teaching, the latter proves fruitful, since the LESLLA landscape consists of several communities.

The thesis also highlights, in line with e.g. Vähäsantanen and Billett (2008) and Vähäsantanen and Eteläpelto (2009), that the teacher identity is formed in particular when changes are brought about in a community and force or inspire teachers to act in a different way. Since there are frequent changes in the field of adult and second language education, this supports the claim that the teacher's identity formation is an ongoing process. One example of what change means for the teacher identity are the implications that 
digitalisation has had. Indirectly, the current curriculum urges the teacher to teach the students to use digital tools (Swedish National Agency for Education, 2012), and one consequence of this is that literacy has become multimodal (see Jewitt, 2008). The teacher must adjust her/his teaching to support the students in their literacy development. The digital tools used for both teaching and learning have not only come to reify the teaching practice, they also imply that the teacher needs to reify her/himself as a teacher by negotiating what it means for the teaching of literacy (see Wenger, 1998).

Moreover, that the teacher identity is dynamic means that it is difficult to separate the teacher's being from her/his becoming. One thing gives the other. Being is not static: it implies becoming. Being is what the teacher does, her/his actions, but also how s/he experiences these actions in the practice (see Wenger 1998). By entering and by continuously participating in a certain community, as well as taking a trajectory in the LESLLA landscape, the teacher is becoming. As Beijaard, Meijer and Verloop (2004, p. 122) conclude, this implies that teacher identity answers the question not only of who one is at the moment but also who one wishes to become.

\section{... evolving in multiple communities...}

A LESLLA teacher's being and becoming is related, not only to time, but also to space. The study has shown that it is a process that takes place simultaneously in a number of different communities. The landscape metaphor (see e.g. Wenger, 2010) is useful to understand how these parallel learning trajectories contribute to the formation of the professional teacher identity. With one exception, the significance of a community in the LESLLA teaching landscape differs from teacher to teacher. The teaching and learning practice appears as the most central of all professional communities to which the teacher belongs. I maintain that the teaching and learning practice lies in the centre of the LESLLA landscape, and, thus, it is not surprising that it means much for the teachers' identity. Students' learning, the primary goal of the teaching and learning practice, is also the overall goal of for example the whole SFI 
education. This means that it, indirectly, is also an enterprise (see Wenger, 1998) of all the surrounding professional communities. The work team, for example, is to facilitate teacher cooperation and the organization of teaching, at the same time as participation within it implies that the teachers learn about LESLLA teaching from each other. Likewise, an imagined membership in the overall SFI teacher or the bilingual teacher community, as well as alignment to the steering documents in these practices, will affect the teacher's teaching actions.

The question arises whether communities in which the teacher engages are more important for the teacher identity than the imagined communities or is this something that differs from one teacher to another? The former possibility is indicated by one of the substudies. However, other findings illustrate that the overall imagined community of LESLLA teachers has a certain significance. This membership, visible in how a teacher identifies her/himself in regard to the particular nature of the LESLLA learners, is a community that unifies teachers engaged in different local contexts and/or in the communities of SFI teachers and mother tongue teachers. One conclusion is that a dividing line cannot be drawn between the different types of membership in a community. Instead, a community's significance may be related to whether the teacher gains access to it or not, and whether s/he can align with its regime of competence. A parallel can be drawn to what Hökkä et al. (2008) have found. The teachers in their study identified with other teachers who taught the same subject. This was since they did not collaborate much with other groups. Also, Hodkinson and Hodkinson (2004, p. 30) have observed that different school communities in terms of subject departments implied different learning practices for its members. This too, may be the reason why some communities become more significant for the LESLLA teachers. This thesis shows that the teachers' preferences for learning opportunities differ.

\section{...in regard to power relations}

The study has shown that the LESLLA teacher identity, whether with respect to the social influence from the macro level, the 
teacher's membership in different communities, or the teacher's individual biography, is formed and constructed in regard to power relations. It shows an ambiguousness of the teacher as someone who possesses power at the same times as $\mathrm{s} / \mathrm{he}$ is subordinate to other forces. The teacher's participation in the local communities, and the ways in which s/he often presents her/himself, speak of her/him as powerful. Just as Vähäsantanen (2015) states, the teacher's professional agency is both socially and individually resourced. As Vähäsantanen and Eteläpelto (2009) have shown, the teacher's response to reforms is related to her/his individual experience of work as well as to her/his future prospects. Also, the thesis indicates that the work team community and other local teacher communities are crucial for teachers to experience themselves as powerful. As Rappel (2015, p. 324) points out, an authentic conversation and a secure and stable workplace are essential for teachers. They need to trust themselves, as well as others, to link the agenda and the objectives of the workplace to their individual backgrounds.

At the same time, however, the teacher's acting space is limited and s/he experiences a lack of power. For example, this is related to how the school organises their work, to the regulations coming from above, and to an underlying language hegemony. Accordingly, the teacher is involved in an ongoing struggle about power. An example is that some teachers considered leaving their work positions when the external expectations on them did not correspond with their picture of what the work should imply. A parallel can be drawn to the studies of Liu and Xu (2011; 2013), in which teachers chose an outbound trajectory from a community, since they could not align to the required changes. Both in these studies and in the thesis, the teacher experienced change, which required an unwanted shift in their identities. Moreover, this result supports what Nicoll and Edwards (2012) state - that the teacher's dispositions and commitment are to be negotiated in regard to his or her work practice and the standard requirements of competence.

There are different ways to understand how power, in this sense, contributes to the LESLLA teacher identity. One is to apply the regime of competence. Some communities are more influential in the landscape, since what they produce is given a higher value (Wenger, 2010, p.11). Consequently, the competences 
acknowledged in a LESLLA work team community do not, necessarily, have the same value in other school communities. Likewise, values that are esteemed in an imagined LESLLA teacher community can be misrecognized in others. An example of such differences is seen in that the SFI teacher according to the law, should be primarily employed on the basis of her/his formal qualifications, i.e. her/his institutional capital. This is what is valued if one aligns to the SFI regulations. But the regime of competence, both in the imagined and the local LESLLA teacher communities, highlights other types of competence for facilitating the students' learning, i.e. pursuing its joint enterprise (see Wenger 1998). As has been previously discussed, the competences of considering and adjusting to the needs of the students, caring for them and acting as bridge builders are esteemed in these communities.

Likewise, the mother tongue teacher, by belonging to a bilingual teacher community, rather stresses the ability to understand the students' needs due to one's linguistic and/or cultural competencies than the value of speaking a standard variety of the Swedish language.

Another way to comprehend the power struggle is to turn to the Bourdieuan concepts of field and capital. From this perspective, the teacher, individually and together with other teachers, positions her/himself (see Bourdieu, 1998, p. 32) with for example the embodied LESLLA capital of caring and bridge-building competence. Since the teacher possesses these types of capital, s/he can be acknowledged as a professional, but at the same time, s/he needs to claim that these competencies are valuable in the field of LESLLA (see Bourdieu \& Wacquant, 1992, p. 98). As WengerTrayner and Wenger-Trayner (2015, p. 16) point out, many voices compete in a landscape and some are silenced by others. Since there are competing claims in the overall field, the capital of being acknowledged in some communities is not automatically given a hearing in others.

The examples given above provide a hint for comprehending the relationship between the regime of competence, on the one hand, and capital and field, on the other. Competence and capital resemble each other since both represent what the teacher has learned and/or possesses in terms of actual abilities (embodied capital) and/or formal abilities (teacher qualifications and other 
institutionalised capital). The competence that is acknowledged in a certain community constitutes symbolic capital, and this is constantly negotiated (see Bourdieu, 1998, p. 47).

\section{Synthesising remarks}

The four substudies on which this thesis is based are intertwined. In the continuing process of developing professional identity, the teacher participates in a multitude of communities in the landscape of LESLLA teaching. Power plays an essential part in the trajectories within and across the communities in the landscape, where the teacher negotiates both her/his capital and the regime of competence in the communities to which s/he belongs. In the landscape, the different communities compete with each other (Wenger-Trayner \& Wenger-Trayner, 2015, p. 16).

The teacher's development is ultimately, if not only, related to social structures. Previous research (e.g. Carlson 2002; Holliday, 2006; Zachrison, 2014) has shown, for example, that the outlook on the learners and language used in teaching depends on societal norms and societal transformations. Several studies (e.g. Wahlgren, 2016; Sava Luopo, 2009) point out that adult educators are a professional group, which has recently received a lot of attention in the politics of education. These studies show also that there are many emerging policies on the macro level that govern the professionalization of teachers. This is also the case for teachers in SFI (see Lindberg \& Sandwall, 2012). The many policy changes issued by politicians and civil servants not only reflect that the teacher identity is required to change constantly, but also indicate that the teacher's professional status is low. In this, s/he has little to say her/himself, and this contributes to undermine the teacher's autonomy.

Due to this situation, the LESLLA teacher strives for acknowledgement. This concerns the competences and capital that are valued. Even if some competences are generally recognized by the LESLLA teachers, they differ from community to community in the landscape. For example, whereas the ability to speak a student's mother tongue is stressed both in some of the local school communities and in the community of bilingual teachers, other 
communities promote other competences. Likewise, the values and the actions in different communities can oppose each other. All this implies that the teacher must navigate and negotiate within the communities and the landscapes of SFI and LESLLA teaching. In this sense, the power aspect is an essential contribution to situated learning.

\section{Critical reflections}

This study has strengths and weaknesses. One of its strengths is that it deals with an understudied context - highlighting a group of teachers who have often been overlooked in spite of their very complex role and challenging mission.

Secondly, it is a strength that the study deals with the LESLLA teachers in different contexts. Even if the study does not aim to compare what being and becoming a teacher means in different local educational settings, the findings indicate that there are significant aspects that contribute to the teacher identity regardless of the setting. LESLLA teachers in municipality schools, private schools and folk high schools share many experiences and negotiate their identity with similar arguments. This implies the transferability of the study (see Lincoln \& Guba, 1985, p. 316).

Also, the fact that the LESLLA teacher identity is treated from different angles is a strength. The four research questions include how the teachers acted, learned and negotiated their memberships in different communities and thus, the study includes both micro and macro aspects.

However, some aspects of the study could be improved. Since the focus of each substudy was different, not all schools were included in all of the substudies. Generally, this was not a problem. When studying teachers teaching with a mother tongue as a tool, for example, it was natural to select schools where such teachers worked. The selection of data used in the second article, however, is slightly problematic. In this case, I omitted the teachers from a school from which I had already collected data. The choice was rooted in that I wanted to explore whether there are any differences in teacher identity between a municipality school and a folk high school. Since I could not see any differences, the focus shifted 
during the analysis, but since I already had the data I did not consider including the data from the school that had been omitted on the basis of the previous focus. In practice, it means that three teacher interviews that may have shed further light onto the transition from one teaching practice/landscape to another were not included. However, since these were the first main interviews I conducted, they were tentative, and did not contain much data on the learning trajectory of a new LESLLA teacher.

Another weakness is that the theories applied do not provide tools for analyzing how gender contributes to the teachers' identity formation. Since the majority of the LESLLA and SFI teachers are women, it could have been fruitful to explore how gender issues are used in the negotiation of identity. However, it is difficult to squeeze too many theoretical perspectives into one thesis. Situated learning has enabled me to understand the complexity of the LESLLA teacher identity, given that there are so many social relationships in many different settings and on many different levels that contribute to it. Also, it has provided tools for analyzing actions, self-conceptions and trajectories. The Bourdieuan concepts, moreover, have been useful for revealing the aspects of power that constitute and shape social practices.

\section{Implications and future research}

In this thesis, I have analysed different aspects of what it means to be a LESLLA teacher and how the professional identity is formed and constructed. The LESLLA teacher appears as a professional who teaches a particular group of learners and who, due to her/his membership in a number of communities in the landscape of LESLLA practices and beyond, constantly develops. I have illustrated this process by focusing on different aspects of the identity formation: the learning when participating in different communities (for example through teaching) and on how the teacher negotiates her/his membership in these in regard to for example social structures and societal changes.

The study indicates that it would be beneficial for LESLLA teachers to receive more education in what it can mean to teach adults. The teachers who are new in the landscape of LESLLA 
generally know little about educating adults, even if they often have experience of teaching in other contexts. However, since adult education is a heterogeneous field with many types of learners and with different aims and focuses, the teachers need opportunities to combine the perspectives of the LESLLA learner as an adult, emergent reader and second language learner. It is possible that such opportunities should be combined with general knowledge in the field of adult education.

LESLLA teachers, as well as SFI teachers in general, are understudied as groups of professionals. Not least in regard to the learners they have, they deserve more attention in research. A number of questions arising from this study could contribute to narrowing this gap. Due to the fact that a vast majority of the LESLLA teachers, especially the ones employed as SFI teachers, are women, one suggestion is to apply a gender perspective in a study of LESLLA teacher identity. Also, it would be interesting to continue to explore the power relationships between different groups of teachers, based on ethnicity and language and positions. In recent years, more SFI schools have come to employ teacher assistants who speak a mother tongue of the students, rather than employing mother tongue teachers. In what way does this contribute to the LESLLA teacher identity and what does this mean for the organisation of the teaching? Likewise, it would be fruitful to study in more depth the role of the power relationships for the SFI teacher identity in regard to the frequent changes of the SFI field. That would highlight how the teacher's work is inseparable from policies in the fields of the labour market, inclusion and integration.

One surprising result was that there is little difference between teachers in the different school systems in terms of their teaching actions, learning trajectories and negotiations of change. It is possible that this can be explained by the teachers and the principals in these particular schools sharing the view that LESLLA teaching implies special conditions. A common understanding was that LESLLA teaching should not be ignored. Moreover, my focus was on the LESLLA teacher identity and not on the professional identity in regard to one's employer. Thus, it would be interesting to explore the professional identity of the SFI teacher and how it depends on the type of educational institution in which the teacher works. For example, what does it mean to be an SFI teacher in a 
folk high school or in a municipal school? What about a school run by a big private company? What does it mean for the teacher's identity when her/his autonomy is either safeguarded or restricted by limited teaching resources and internal school policy? In what way do the differences in the educational traditions and the conditions set by the systems shape the teacher's professionality?

Moreover, it would be fruitful to explore how the teachers use digital tools in teaching. The thesis shows briefly that digitalisation has brought with it huge changes in how the teachers teach, but not much is known about what it means for the teaching and learning practice. By applying a socio-material perspective, it would be possible to comprehend more of this change. This is of particular interest for LESLLA teaching, where the teachers and the learners often have a limited mutual vocabulary and the teaching cannot rely so much on individual text-based material. 


\section{References}

Alfarådet. (2013). Description of teachers competence in initial and functional literacy for adults with non-Nordic mother tongues. Retrieved September 3, 2013, from http://www.nordvux.net/download/7330/english_brochure_for_ printing_with_bleeds.pdf accessed

Andersson, P., Köpsén, S., Larson, A., \& Milana, M. (2012).

Qualification paths of adult educators in Denmark and Sweden.

Studies in Continuing Education, 35(1), 102-118. doi:

10.1080/0158037X.2012.712036

Andersson, P., Rudberg, K., Rydenstam, K., \& Svensson, L. (2013). Att vara folkhögskollärare - förutsättningar, kompetensbehov och tidsanvändning. Stockholm: Folkbildningsrådet.

Avalos, B. (2011). Teacher professional development in Teaching and Teacher Education over ten years. Teaching and Teacher Education, 27, 10-20. doi: 10.1016/j.tate.2010.08.007

Bhatia, T. K. (2017). Bilingualism and multilingualism from a socio-psychological perspective, In M. Aronoff (Ed.), Oxford Research Encyclopedia of Linguistics. doi: 10.1093/acrefore/9780199384655.013.82

Beach, D. (2004). The public cost of the re-structuring of adult education: A case in point from Sweden. Journal for Critical Education Policy Studies, 159-188. Retrieved from https://www.divaportal.org/smash/get/diva2:870514/FULLTEXT01.pdf

Beach, D., \& Carlson, M. (2004). Adult education goes to market: An ethnographic case study of the restructuring and reculturing of adult education. European Educational Research Journal, 3(3), 673-691. Retrieved from http://journals.sagepub.com/doi/pdf/10.2304/eerj.2004.3.3.9

Beauchamp, C., \& Thomas, L. (2009). Understanding teacher identity: An overview of issues in the literature and implications for teacher education. Cambridge Journal of Education, 39(2), 175-189. doi: 10.1080/03057640902902252

Beijaard, D., Meijer, P. C., \& Verloop, N. (2004). Reconsidering research on teachers' professional identity. Teaching and 
Teacher Education, 20, 107-128. doi:

10.1016/j.tate.2003.07.001

Bhola, H. S. (2008). Adult literacy for sustainable development:

Creating a knowledge-based discourse for action. In H. S.

Bhola, \& S. Gomez, Signpost to Literacy for Sustainable

Development. UNESCO Institute for Lifelong Learning.

Bigelow, M. Delmas, R. Hansen, K., \& Tarone, E. (2006). Literacy and the processing of oral recasts in SLA, TESOL Quarterly. 40(4). 665-689. doi: 10.2307/40264303

Bigelow, M., \& Vinogradov, P. (2011). Teaching adult second language learners who are emergent readers. Annual Review of Applied Linguistics, 31, 120-136. doi:

10.1017/S0267190511000109

Bigestans, A. (2015). Utmaningar och möjligheter för utländska lärare som återinträder i yrkeslivet i svensk skola. Stockholm: Stockholm University.

Billett, S. (2004). Learning through work: Workplace participatory practices. In H. Rainbird, A. Fuller, \& A. Munro (Eds.), Workplace learning in context (pp. 109-125). London: Routledge.

Billett, S. (2006). Relational interdependence between social and individual agency in work and working Life. Mind, Culture, and Activity, 13(1), 53-69. doi:

10.1207/s15327884mca1301_5

Billett, S. (2007). Including the missing subject: Placing the personal within the community. In J. Hughes, N. Jewson, \& L. Unwin, Communities of practice: Critical Perspectives (p. 5567). New York: Routledge.

Blaikie, N. (2004). Abduction. In M. S. Lewis-Beck, A.

Bryman \& T. F. Liao (Eds.), The Sage Encyclopaedia of Social Science Research Methods (pp 1-3). doi:

10.4135/9781412950589.n1

Boon, D. (2011). Adult literacy teaching in multilingual TimorLeste. Compare: A Journal of Comparative and International Education, 41(2), 261-276.

Bourdieu, P. (1991). Language and symbolic power. Cambridge: Polity Press.

Bourdieu, P. (1996). The Forms of Capital. In H. Lauder, P. Brown, J. Dillabough, \& A. H. Halsey (Eds.), Education, globalization 
\& social change (pp. 105-118). Oxford: Oxford University Press.

Bourdieu, P. (1998). Practical reason: On the theory of action. Cambridge: Polity Press.

Bourdieu, P., \& Wacquant, L. (1992). An invitation to reflexive sociology. Chicago: University of Chicago Press.

Braun, V., \& Clarke, V. (2006). Using thematic analysis in psychology. Qualitative Research in Psychology, 3(2), 77101. doi: 10/.1191/1478088706qp063oa

Bredänge., G. (2003). Gränslös pedagog: Fyra studier om Utländska lärare $i$ svensk skola. Gothenburg: University of Gothenburg.

Brink, H. I. L. (1993). Validity and reliability in qualitative research. Paper presented at the SA Society of Nurse Researchers' Workshop-RAU. Retrieved from https://curationis.org.za/index.php/curationis/article/download/1 $396 / 1350$

Brinkmann, S. (2014). Unstructured and semi-structured interviewing, In P. Leavy (Ed.), The Oxford handbook of qualitative research (pp. 277-299). New York: Oxford University Press.

Broady, D. (1991). Sociologi och epistemologi: Om Pierre Bourdieus författarskap och den historiska epistemologin. Stockholm HLS förlag.

Buchanan, R. (2015). Teacher identity and agency in an era of accountability. Teacher and Teaching, 21(6). doi:

10.1080/13540602.2015.1044329

Carlson, M. (2002). Svenska för invandrare - brygga eller gräns? Syn på kunskap och lärande inom sfi-undervisningen, Gothenburg: University of Gothenburg.

Colliander, H. (2012). Relations, methods and motivations: A case study of the professional competence of literacy trainers in Sudan. Stockholm: Stockholm University.

Collins, J. \& Blot, R. K. (2003). Literacy and literacies: Texts, power, and identity, New York: Cambridge University Press.

Condelli, L., Wrigley, H. S., \& Yoon, K. S. (2008). The what works study: Instruction, literacy and language learning for Adult ESL Literacy Students. In S. Reder, \& J. Bynner (Eds.), Tracking adult literacy and numeracy skills: Findings from 
longitudinal research (pp. 132-159). London \& New York: Routledge.

Crowther, J., Hamilton, M. \& Tett, L. (2001). Powerful literacies. Leicester: NIACE.

Cummins, J. (2015). How to reverse a legacy of exclusion? Identifying high-impact educational responses. Language and Education, 29(3), 272-279. doi: 10.1080/09500782.2014.994528

Evetts, J. (2012). Professionalism in turbulent times: Changes, challenges and opportunities. Paper presented at the Propel International Conference, Stirling. Retrieved from https://www.yumpu.com/en/document/view/12242124/fullpaper-professionalism-in-turbulent-times-changes-propel

Erguig, R. (2012). Teaching as a social practice: The experiences of two Moroccan adult literacy tutors, Studies in the Education of Adults, 44(1), 52-69. doi: 10.1080/02660830.2012.11661623

Fangen, K. (2005). Deltagande observation Stockholm: Liber. Farnsworth, V., Kleanthous, I., \& Wenger-Trayner, E. (2016). Communities of practice as a social theory of learning: A conversation with Etienne Wenger, British Journal of Educational Studies, 139-160. doi:

10.1080/00071005.2015.1133799

Farrelly, R. E., (2012). Emerging from the echo chamber: An activity theory perspective on L2 teachers of adult emergent readers. Department of Linguistics. Salt Lake City: University of Utah.

Fejes, A., Runesdotter, C., \& Wärvik, G. (2016). Marketisation of adult education: Principals as business leaders, standardised teachers and responsibilised students, International Journal of Lifelong Education, 35(6), 664-681. doi: 10.1080/02601370.2016.1204366

Franker, Q. (2013). Att utveckla litteracitet i vuxen ålder alfabetisering i en tvåspråkig kontext. In K. Hyltenstam, \& I. Lindberg (Eds.), Svenska som andraspråk: - i forskning, undervisning och samhälle (pp. 675-712). Lund:

Studentlitteratur.

Franker, Q. (2007). Bildval i alfabetiseringsundervisningen: - En fråga om synsätt. Gothenburg: University of Gothenburg.

Freeman, D., \& Johnson, K. (1998). Reconceptualizing the 
knowledge-base of language teacher education. TESOL Quarterly, 397-417. doi: 10.2307/3588114

Fuller, A., Hodkinson, H., Hodkinson, P., \& Unwin, L. (2005).

Learning as peripheral participation in communities of practice:

A reassessment of key concepts in workplace learning. British

Educational Research Journal, 31(1), 49-68. doi:

10.1080/0141192052000310029

Fylan, F. (2005). Semi-structured interviewing. In P: Gilbert \& J.

Miles (Eds.), A handbook of research methods for clinical and health psychology (pp. 65-77). Oxford: Oxford University Press.

Ganuza, N., \& Hedman, C. (2015). Struggles for legitimacy in mother tongue instruction in Sweden. Language and Education, 29(2), 125-139. doi: 10.1080/09500782.2014.978871

Garcia, O. (2009). Bilingual education in the 21st century: A global perspective. Malden, Ma: Wiley-Blackwell.

Gee, J. P. (2011). Social linguistics and literacies: Ideology in discourses. (3rd ed.). London: Routledge.

Goody, J. \& Watt. I. (1963). The consequences of literacy. Comparative Studies in Society and History. 5(3). 304-345.

Guimãraes, P. (2009) Reflections on the professionalisation of educators in the framework of public politics in Portugal. European Journal of Education 44(2), 205-219. doi: 10.1111/j.1465-3435.2009.01379.x

Hammersley, M., \& Atkinson, P. (2007). Ethnography: Principles in practice. (3rd ed.) London and New York: Routledge.

Hamilton, M., Hillier, Y., \& Tett, L. (2006). Introduction: Social practice of adult literacy, numeracy and language. In L. Tett, M. Hamilton, \& Y. Hillier (Eds.), Adult Literacy, Numeracy and Language: Policy, Practice and Research (pp. 1-18). Maidenhead: Open University Press.

Handley, K., Sturdy, A., Fincham, R., \& Clark, T. (2006). Within and beyond communities of practice: Making sense of learning trough participation, identity and practice. Journal of Management Studies, 43(3), 641-653.

Handley, K., Clark, T., Fincham, R., \& Sturdy, A. (2007). Researching situated learning: Participation, identity and practices in client: Consultant relationships, Management 
Learning. 38(2), 173-191.

Hillier, H., \& DiLuzio, L. (2004). The interviewee and the research interview: Analysing a neglected dimension in research. Canadian Review of Sociology/Revue canadienne de sociologie 41(1): 1-26. doi: 10.1111/j.1755618X.2004.tb02167.x

Hodkinson, P., \& Hodkinson, H. (2003). Individuals, communities of practice and the policy Context: School teachers' learning in their workplace. Studies in Continuing Education, 25(1), 3-21. doi: 10.1080/01580370309284

Hodkinson, H., \& Hodkinson, P. (2004). Rethinking the concept of community of practice in relation to schoolteachers' workplace's learning. International Journal of Training and Development, 8(1), 21-32. doi: 10.1111/j.13603736.2004.00193.x

Holliday, A. (2006). Native-speakerism. ELT Journal, 60(4), 385387. doi: 10.1093/elt/ccl030

Hydén, L. (2008). Analys av berättelser i forskningsintervjuer. In S. Larsson, Y. Sjöblom, \& J. Lilja, Narrativa metoder i socialt arbete (pp. 111-132). Lund: Studentlitteratur.

Hökkä, P., Rasku-Puttonen, H., \& Eteläpelto, A. (2008). Teacher educators' workplace learning: The interdependency between individual agency and social context. In S. Billett, \& C. Harteis, A. Eteläpelto (Eds.), Emerging perspectives of workplace learning (pp. 51-65). Rotterdam: Sense Publishers.

Hökkä, P., Vähäsantanen, K. \& Mahlakaarto, S. (2017). Teacher educators' collective professional agency and identity: Transforming marginality to strength. Teaching and Teacher Education 63, 36-46. doi: 10.1016/j.tate.2016.12.001

Jewitt, C. (2008). Multimodality and literacy in school classrooms. Review of Research in Education, 32, 241267. doi: 10.3102/0091732X07310586

Kanno, Y., \& Stuart, C. (2011). Learning to become a second language teacher: Identities-in-practice. The Modern Language Journal, 95(2), 236-252. doi: 10.1111/j.15404781.2011.01178.x

Karlsson, S. (2002). Transkription - teori och praktik. University of Gothenburg.

Kress, G. (2003). Literacy in the new media age. London and New 
York: Routledge.

Kvale, S., \& Brinkmann, S. (2009). Den kvalitativa forskningsintervjun. Lund: Studentlitteratur.

Larsson, S. (2005). On quality of qualitative studies. Nordisk Pedagogik, 22, 16-35.

Larsson, S. (2006). Didaktik för vuxna - tankelinjer i internationell litteratur. Stockholm: Swedish Research Council.

Larsson, S. (2009). A pluralist view of generalization in qualitative research. International Journal of Research \& Method in Education, 23(1) 25-38. doi: 10.1080/17437270902759931

Lasky, S. (2005). A sociocultural approach to understand teacher identity, agency and professional vulnerability in a context of secondary school reform. Teacher and Teacher Education 21(8), 899-916. doi: 10.1016/j.tate.2005.06.003

Lattke, S. \& Jutte, W. (2015). Professionalisation of adult educators: International and comparative perspectives. Frankfurt am Main: Peter Lang AG.

Lave, J. (1991). Situated learning in communities of practice. In L. B. Resnick, J. M. Levine, \& S. D. Teasley (Eds.), Perspectives on socially shared cognition (pp. 63-82). n.a.: American Psychological Association.

Lave, J., \& Wenger, E. (1991). Situated learning: Legitimate peripheral participation. Cambridge: Cambridge University Press.

Lincoln, Y., S. \& Guba, E., G. (1985). Naturalistic Inquiry. Newbury Park: Sage Publications.

Lindberg, I., \& Sandwall, K. (2007). Nobody's darling? Swedish for adult immigrants: A critical perspective. Prospect, 22(3), 79-95

Lindberg, I., \& Sandwall, K. (2012). Samhälls- och undervisningsperspektiv på svenska som andraspråk för vuxna invandrare. In K. Hyltenstam, M. Axelsson \& I. Lindberg (Eds.), Flerspråkighet - En forskningsöversikt (pp. 368-502). The Swedish Research Council.

Liu Y., \& Fisher, L. (2006). The development patterns of modern foreign language student teachers' conceptions of self and their explanations about change: Three cases. Teacher Development: An international journal of teachers' professional development, 10(3), 343-360, doi:10.1080/13664530600922203 
Liu, Y., \& Xu, Y. (2011). Inclusion or exclusion?: A narrative inquiry of a language teacher's identity and experience in the 'new work order' of competing pedagogies. Teacher and Teacher Education, 27(3), 589-597. doi: 10.1016/j.tate.2010.10.013

Liu, Y., \& Xu, Y. (2013). The trajectory of learning in a teacher community of practice: A narrative inquiry of a language teacher's identity in the workplace. Research Papers in Education, 28(2), 176-195. doi: 10.1080/02671522.2011.610899

Luke, A. (1998). Getting over method: Literacy teaching as work in "new times", Language Arts, 75(4), 305-313.

Lundgren, B. (2005). Skolan i livet - livet i skolan. Umeå: Umeå University.

Magro, K. (2008). Exploring the experiences and challenges of adults from war-affected backgrounds: New directions for literacy educators. Adult Basic Education and Literacy Journal, 2(1), 24-33.

McCarty, T., Collins, J., \& Hopson, R. (2011). Dell Hymes and the new language policy studies: Update from an underdeveloped country. Anthropology \& Education Quarterly, 42(4), 335-363. doi: 10.1111/j.1548-1492.2011.01143.x

Milana, M., Andersson, P., Farinelli, F., Gross, M., Jõgi, L., Köpsén, S., \& Larson, A. (2010). BAEA - Becoming Adult Educators in the European Area. Synthesis research report. Copenhagen: Danish School of Education. Aarhus University.

Ministry of Education, (2013). SOU 2013:76 Svenska för invandrare - valfrihet, flexibilitiet och individanpassning Retrieved from http://www.regeringen.se/49b715/contentassets/b158c540ef124 967b6d04c11cd931609/svenska-for-invandrare--valfrihetflexibilitet-och-individanpassning-del-1-av-2-forord-ochkapitel-1-7-sou-201376

Narrowe, J. (1998). Under one roof: On becoming a Turk in Sweden. Stockholm: Almqvist \& Wiksell International. National Centre for SFI and Swedish as a Second Language. (2007). Alfabetiseringsutbildning $i$ Norden. Retrieved from http://www.andrasprak.su.se/polopoly_fs/1.47850.1326708235! /kanprojektet.pdf 
National Centre for Swedish as a Second Language (2008). Den ämnesteoretiska kunskapsbasen för sfi-läraruppdraget - och om professionalitet, professionalisering och behovet av en formell utbildning för sfi-lärare. Stockholm University.

National Centre for Swedish as a Second Language. (2012).

För låga krav på Sfi-lärare. Retrieved from:

www.andrasprak.su.se/om-oss/aktuellt/för-låga-krav-på-sfilärare-1.116523

National Centre for Swedish as a Second Language. (2013).

Nätverk för lärare och skolledare inom sfi på folkhögskolan. Retrieved February 2014, from www.andrasprak.su.se/sfivuxenutbildning/nätverk/nätverk-för-larare-och-skolledare-påfolkhögskolan.190434

Nicolini, D., Gherardi, S., \& Yanow, D. (2003). Introduction:

Toward a practice-based view of knowing and learning in organizations. In D. Nicolini, S. Gherardi, \& D. Yanow (Eds.), Knowing in organizations: A practice-based approach (pp. 328). Armonk, New York: M.E. Sharpe.

Nicoll, K., \& Edwards, R. (2012). Positioning adult educators in discourses of professional development. Studies in Continuing Education, 34(3). 233-249. doi :

10.1080/0158037X.2011.646980

Ollis, T. (2011). Learning in social action: The informal and social learning dimensions of circumstantial and lifelong activists, Australian Journal of Adult Learning, 51(2), 248-268.

Ong, W. J. (1982). Orality and literacy: The technologizing of the word. London: Methuen.

Perry , K. H., \& Homan, A. (2015). "What I feel in my heart":

Literacy practices of and for the self among adults with limited or no schooling. Journal of Literacy Research, 46(4), 422-454. doi: 0.1177/1086296X14568839

Perry, K. H., \& Hart, S. J. (2012). "I'm Just Kind of Winging It": Preparing and supporting educators of adult refugee learners. Journal of Adolescent \& Adult Literacy 56(2), 110122. doi: 10.1002/JAAL.00112

Rappel, L. J. (2015). Integrating the personal and the professional: Marking the career paths of adult language educators. Adult Education Quarterly, 65(4), 313-325. doi:

$10.1177 / 0741713615585573$ 
Rubinstein Reich, L., \& Jönsson, A. (2006). Invandrade lärares arbetssituation och läraridentitet - efter fyra år som lärare i den svenska skolan. Educare, 2, 66-107.

Sachs, L. (1986). Alfabetisering: en fråga om kultur och tänkande. Linköping: Linköping University.

Sachs, J. (2005). Teacher education and the development of professional identity: Learning to be a teacher. In M Kompf \& P. Denicolo (Eds.), Connecting Policy and Practice: Challenges for Teaching and Learning in Schools and Universities (pp. 7-21). Abingdon: Routledge

Salminen-Karlsson, M. (2006). Situating gender in situated learning. Scandinavian Journal of Management, 22(1), 31-48. doi: 10.1016/j.scaman.2005.05.005

Sandwall, K. (2010). "I learn more at school": A critical perspective on workplace-related second language learning in and out of school. TESOL Quarterly, 44(3), 542-574. Doi: $10.5054 /$ tq. 2010.229270

Sandwall, K. (2013). Att hantera praktiken: Om sfi-studerandes möjligheter till interaktion och lärande på praktikplatser Gothenburg: University of Gothenburg.

Sanguinetti, J., Waterhouse, P., \& Maunders, D. (2005). Pedagogies on the edge: Researching complex practice in youth and adult community education. Studies in Continuing Education, 27(3) 271-287. doi: 10.1080/01580370500394252

Sava, S., \& Lupou, R. (2009). The adult educator in Europe professionalisation, challenges and the alternative validation of learning outcomes. Procedia - Social and Behavioral Sciences 1, 2227-2232. doi: 10.1016/j.sbspro.2009.01.392

SKOLFS, 2006:28. Förordning om kursplan för svenskundervisning för invandrare. Retrieved from https://www.skolverket.se/regelverk/skolfs/skolfs?_xurl_=http\% 3A\%2F\%2Fwww5.skolverket.se\%2Fwtpub\%2Fws\%2Fskolfs $\%$ 2Fwpubext\%2Ffs\%2FRecord\%3Fk\%3D1263

SKOLFS 2009:2. Förordning om kursplan för svenskundervisning för invandrare. Retrieved from https://www.skolverket.se/regelverk/skolfs/skolfs?_xurl_http $\% 3 \mathrm{~A} \% 2 \mathrm{~F} \% 2 \mathrm{Fwww} 5$. skolverket.se\%2Fwtpub\%2Fws\%2Fskolf s\%2Fwpubext\%2Ffs\%2FRecord\%3Fk\%3D1491

SFS 2010:197. Lag (2010:197) om etableringsinsatser för vissa 
nyanlända invandrare. Retrieved from

https://www.riksdagen.se/sv/dokument-lagar/dokument/svenskforfattningssamling/lag-2010197-om-etableringsinsatser-forvissa_sfs-2010-197

Street, B. (1984). Literacy in theory and practice. New York:

Cambridge University Press.

Street, B. (2003). What's 'new' in New Literacy Studies? Critical approaches to literacy in theory and practice. Current issues in Comparative Education, 5(2), 77-91.

Sun, Y. (2010). Standards, equity and advocacy: Employment conditions of ESOL teachers in adult basic education and literacy systems. TESOL Journal, 1(1)142-158. doi: $10.5054 / \mathrm{tj} .2010 .215135$

Swedish National Agency for Education. (2012).

Kommunal vuxenutbildning i svenska för invandrare: Kursplan och kommentarer. Retrieved from

https://www.skolverket.se/om-skolverket/publikationer/visaenskild-

publikation?_xurl_=http $\% 3 \mathrm{~A} \% 2 \mathrm{~F} \% 2 \mathrm{Fwww} 5$. skolverket.se $\% 2 \mathrm{~F}$ wtpub\%2Fws \%2Fskolbok\%2Fwpubext\%2Ftrycksak\%2FRecor $\mathrm{d} \% 3 \mathrm{Fk} \% 3 \mathrm{D} 2939$

Swedish National Agency for Education. (2015). Krav för att få undervisa. Retrieved from https://www.skolverket.se/kompetens-ochfortbildning/lararlegitimation/regelverk/krav-for-fa-undervisa1.237066

Swedish National Agency for Education. (2016a). Rätten till att utveckla sitt modersmål. Retrieved from https://www.skolverket.se/regelverk/mer-om-skolansansvar/ratten-till-att-utveckla-sitt-modersmal-1.239311

Swedish National Agency for Education. (2016b).

Modersmålets roll i skriftspråksutveckling. Retrieved from https://www.skolverket.se/skolutveckling/larande/litteracitetsut veckling/modersmalets-roll-i-skriftspraksutveckling-1.254037

Swedish National Agency for Education. (2016c). Sfi på folkhögskola. Retrieved from https://www.skolverket.se/laroplaner-amnen-ochkurser/vuxenutbildning/komvux/sfi/sfi-pa-folkhogskola1.198041 
Swedish National Agency for Education. (2017a). Tabell 3A: Elever 2011-2015 efter kön, ålder, utbildningsbakgrund, andel i läs- och skrivinlärning och anordnare: Retrieved from www.skolverket.se/statistik-och-utvardering/statistik-itabeller/utbildning-i-svenska-for-invandrare/elever-ochkursdeltagare/elever-och-kursdeltagare-i-utbildning-i-svenskafor-invandrare-sfi-kalenderar-2015-1.250835

Swedish National Agency for Education. (2017b). Tabell 5: Anställda med lärarlegitimation 2016/17. Retrieved from www.skolverket.se/statistik-och-utvardering/statistik-itabeller/utbildning-i-svenska-for-invandrare/elever-ochkursdeltagare

Swedish National Agency for Education. (2017c). Tabell 2: Pedagogisk högskoleexamen, anställningsslag och lärartäthet läsåren 2003/04-2016/17. Retrieved from www.skolverket.se/statistik-och-utvardering/statistik-itabeller/utbildning-i-svenska-for-invandrare/personal Swedish National Agency for Education. (2017d). Krav för att få behörighet. Retrieved from www.skolverket.se/kompetensoch-fortbildning/lararlegitimation/regelverk/krav-for-att-fabehorighet-1.237096

Swedish National Agency for Education. (2017e). PM - elever och studieresultat $i$ kommunal vuxenutbildning $i$ svenska för invandrare år 2016. Retrieved from https://www.skolverket.se/om-skolverket/publikationer/visaenskild-

publikation?_xurl_=http $\% 3 \mathrm{~A} \% 2 \mathrm{~F} \% 2 \mathrm{Fwww}$.skolverket.se $\% 2 \mathrm{~F}$ wtpub $\% 2$ Fws $\% 2$ Fskolbok $\% 2$ Fwpubext $\% 2$ Ftrycksak $\% 2$ FRecor $\mathrm{d} \% 3 \mathrm{Fk} \% 3 \mathrm{D} 3799$

Swedish Research Council. (2017). God forskningssed. Retrieved from https://publikationer.vr.se/produkt/godforskningssed/

Tarone, E. (2010). Second language acquisition by low-literate learners: An understudied population. Language Teaching, 43(1), 75-83. doi: 10.1017/S0261444809005734

Tarone E., \& Allwright, D. (2005). Second language teacher learning and student second language learning: Shaping the knowledge base. In D. J. Tedick (Ed.), Second language 
teacher education: International perspectives. pp. 5-23. Mahwah, NJ: Lawrence Erlbaum Associates Publishers. Taylor, E. (2003). The relationship between the prior school lives of adult educators and their beliefs about teaching adults. International Journal of Lifelong Education, 22(1), 59-77. doi $10.1080 / 02601370304828$

Tett, L., \& St. Clair, R. (2010). Adult literacy education. In P. Peterson, E. Baker, \& B. McGaw (Eds.), International Encyclopedia of Education (3rd ed., pp. 107-112). Amsterdam: Elsevier Science \& Technology Books. doi: 10.1016/B978-008-044894-7.00019-1

Thomas, M., \& Pettitt, N. (2017). Informed in research on second language acquisition. Second Language Research, 33(2) 271288. doi: $10.1177 / 0267658316670206$

Thomas, W. P., \& Collier, V. (1997). School effectiveness for language minority students. Washington, DC: National Clearinghouse for Bilingual Education.

Thomas, W. P., \& Collier, V. (2002). A national study of school effectiveness for language minority students' long-term academic achievement. Center for Research on Education, Diversity and Excellence. Santa Cruz: University of California.

Trigwell, K., Prosser, M., \& Waterhouse, F. (1999). Relations between teachers' approaches to teaching and students' approaches to learning. Higher Education, 37, 57-70.

Tsui, A. B. M. (2007). Complexities of identity formation. A narrative inquiry of an EFL teacher. TESOL Quarterly 41(4), 657-680. doi: 10.1002/j.1545-7249.2007.tb00098.x

UNESCO Institute for Statistics. (2017). Literacy rates continue to rise from one generation to the next. Retrieved from http://uis.unesco.org/en/topic/literacy

UNESCO. (n.d.). Workshop 4: Quality education and the key roles of teachers. Retrieved from www.ibe.unesco.org/international/ICE47/English/Organisation/ Workshops/Background\%20at-4\%20ENG.pdf

United Nations, Department of Economics and Social Affairs (2017). International Migration Report 2017. Retrieved from https://www.un.org/development/desa/publications/internationa 1-migration-report-2017.html

Valenta, M. (2009). 'Who wants to be a travelling teacher?' 
Bilingual teachers and weak forms of bilingual education: The Norwegian experience. European Journal of Teacher Education, 32(1), 21-33.

Vincent, C., \& Warren, S. (2001). "This won't take long...": Interviewing, ethics and diversity. Qualitative Studies in Education, 14(1), 39-53. doi: 10.1080/09518390010007674 Vinogradov, P., \& Liden, A. (2009). Principled training for LESLLA instructors. In I van de Craats, \% J. Kurvers (Eds.), Low-educated second language and literacy acquisition: Proceedings from 4th Annual LESLLA Symposium (pp. 133144). Antwerp, Belgium. Retrieved from https://www.researchgate.net/profile/I_Craats/publication/2547 92357_A_yearly_tradition_Research_practice_and_policy_on_ low-

educated_second_language_and_literacy_learners/links/53fbbb $8 \mathrm{f} 0 \mathrm{cf} 2 \mathrm{dca} 8 \mathrm{fffec} 4 \mathrm{ea} / \mathrm{A}$-yearly-tradition-Research-practice-andpolicy-on-low-educated-second-language-and-literacylearners.pdf

Vinogradov, P. (2013a). Defining the LESLLA teacher knowledge base. In T. Tammelin-Laine, L. Nieminen, \& M. Martin (Eds.), Low-educated second language and literacy acquisitions. Proceedings of the 8th symposium (pp. 9-24). Jyväskylä: Jyväskylä University Printing House.

Vinogradov, P. (2013b). Professional learning across contexts for LESLLA teachers: The unlikely meeting of adult educators in kindergarten to explore early literacy instruction.

University of Minnesota: Minnesota.

Vähäsantanen, K. (2015). Professional agency in the stream of change: Understanding educational change and teachers' professional identities. Teaching and Teacher Education, 47, 112. doi: 10.1016/j.tate.2014.11.006

Vähäsantanen, K., \& Billett, S. (2008). Negotiating professional Identity: Vocational teachers' personal strategies in a reform context. In S. Billett, C. Harteis, \& A. Eteläpelto (Eds.), Emerging perspectives of workplace learning (pp. 35-49). Rotterdam: Sense Publishers.

Vähäsantanen, K., \& Eteläpelto, A. (2009). Vocational teachers in the face of a major educational reform: Individual ways of negotiating professional identities. Journal of Education and 
Work, 22(1), 15-33. doi: 10.1080/13639080802709620

Wahlgren, B. (2016). Adult educators' core competences,

International Review of Education, 62(3), 343-353, doi:

10.1007/s11159-016-9559-4

Watson, J. (2010). Interpreting across the abyss: A hermeneutic

exploration of initial literacy development by high school

English language learners with limited formal schooling.

Minneapolis, MN: University of Minnesota.

Wenger, E. (1998). Communities of practice: Learning, meaning, and identity. New York: Cambridge University Press.

Wenger, E. (2003). Communities of practice and social learning

systems. In D. Nicolini, S. Gherardi, \& D. Yanow, (Eds.),

Knowing in organizations: A practice-based approach (pp. 76-

99). Armonk, NY: M.E. Sharpe.

Wenger, E. (2010). Communities of practice and social learning systems: The career of a concept. In C. Blackmore (Ed.), Social learning systems and communities of practice. (pp. 179-198).

Milton Keynes: Open University.

Wenger-Trayner, E., \& Wenger-Trayner, B. (2015). Theory. In E.

Wenger-Trayner, M. Fenton-O'Creevy, S. Hutchinson, C.

Kubiak, \& B. Wenger-Trayner (Eds.), Learning in landscapes

of practice: Boundaries, identity, and knowledgeability in practice-based learning. (pp. 13-29). Abingdon: Routledge.

Williams, J. D., \& Snipper, G. C. (1990). Literacy and

bilingualism. White Plains, NY: Longman.

Zachrison, M. (2014). Invisible voices. Malmö and Linköping:

Malmö University and Linköping University. 


\section{Appendix A: Observation guide for the teaching practice}

\section{Main questions:}

- What do teachers do?

- In what environment are these actions located?

- What does the teacher need to know in order to act as $\mathrm{s} / \mathrm{he}$ does?

\section{Points of departure:}

Focus on the actions in the lessons. Describe, do not judge. Ask yourself (and the teacher) why s/he is doing what $\mathrm{s} /$ he does. What surprises you?

\section{Focal points:}

a) The physical environment of the teaching practice: The room, the ways of sitting, the number of participants, etc.

b) Time frames: Lesson time, actual time of the teaching, times for break and changes of activities

c) The actors: The relation between the teacher and the students. How the teacher approaches and responds to the learners and vice versa?

d) Actions: What are the general activities and single actions as part of these activities?

e) Physical objects that are of significance for the actions: What objects are used, and how?

f) The way of teaching initial literacy: Reflected in speech and activities (functional, cultural, critical?)

g) Overall pedagogy: For example teacher-centred or learnercentred? 


\section{Appendix B: Interview guide - for the teachers}

\section{Introduction}

Tell the participant that the interview is about her/his history as a LESLLA teacher:

My research project is about how the teachers who teach initial literacy adult learners learn their profession/develop professional identity. Consequently, the big question is how you have become the teacher you are today. What has been important for you in this process? I would like you to tell me your story. Choose where you would like to begin and what you would like to stress. Take your time and describe actions, thoughts and feelings, and the social relationships, that have been part of this development.

When you have told your story, I will follow it up with some questions, and questions about your current work.

Completing questions for the following semi-structured interview

1. About the qualifications necessary to work as a LESLLA teacher:

- Can you describe what is included in your work? What are you doing as a LESLLA teacher? If I was to do your job, what would I do then? Can you describe what it means to work here in this work place?

- What do you need to be, to know, etc.? What abilities (for example knowledge, skills, characteristics and attitudes) do you need to work with LESLLA here at this school? What do you believe that this profession requires?

- What are your strengths as a LESLLA teacher?

- What are your view on initial literacy? 
2. About the trajectory into the LESLLA teaching field of practice:

- If you look back and compare your way of working when you started to work with LESLLA teaching with how you work today, what has changed? (NB! Don't assume that it has changed. But use what has been said in the story of the teacher.)

- How have you changed? How have you developed as a teacher?

- How did you think and feel when you started to work as a LESLLA teacher?

- Is there something in particular you wish to develop more? If so, why this particular thing? What will you be doing in five years' time?

3. About the negotiation of one's membership in different communities

- Which experiences of other types of work (both in terms of teaching occupations and others) do you have?

- In what way have your experiences from other work places and private situations influenced your work? What have you brought to this job from other contexts?

- Which concrete differences can you see from your former work as a teacher and the work as a LESLLA teacher? What have you done to handle these differences?

Depending on what you have noticed in the observation, be prepared to ask the participants more specific questions. 


\section{Appendix C: Interview guide - for a completing interview later in the project}

\section{Introduction}

Tell the participant that the interview is about her/his history as a LESLLA teacher.

My research project is about how the teachers who teach initial literacy adult learners learn their profession/develop professional identity. Consequently, the big question is how you have become the teacher you are today. What has been important for you in this process? I would like you to tell me your story. Choose where you would like to begin and what you would like to stress. Take your time and describe actions, thoughts and feelings, and the social relationships, that have been part of this development.

When you have told your story, I will follow it up with some questions, and questions about your current work.

Completing questions for the following semi-structured interview

About the trajectory into the LESLLA teaching field of practice:

- How did you think and feel when you started to work as a teacher at study track 1 ?

- If you look back and compare your way of working in the beginning with how you work today, in what way have you changed (if at all)?

- What has led to those changes? Is there anything that has meant something special?

- You have been a mother tongue teacher and now you are an SFI teacher. What made you go on and study?

- Which changes have you seen in your time as a teacher in study track 1 ? How have you coped with these changes?

- Is there something in particular you wish to develop more? If so, why this particular thing? What will you be doing in five years' time? 
About the functions of a LESLLA teacher:

- Can you describe what is included in your work? What are you doing as a LESLLA teacher? If I was to do your job, what would I do then? Can you describe what it means to work here in this work place?

- What do you need to be, to know, etc.? What abilities (for example knowledge, skills, characteristics and attitudes) do you need to work with LESLLA here at this school? What do you believe that this profession requires?

- What are your strengths as a LESLLA teacher?

- What are your views on initial literacy?

About the teaching practice in general:

- Has the teaching practice for a teacher in study track 1 changed? How?

- Can you describe how the teaching is organized here at the school, when it comes to the use of the mother tongue? What does a mother tongue teacher, compared to an SFI teacher, do? Are there any differences? If so, which ones?

- How has digitalization influenced your teaching? What does it mean for the students?

Depending on what you have noticed in the observation, be prepared to ask the participants more specific questions. 


\section{Appendix D: Interview guide with the principals}

- Can you tell me about your view on initial literacy education? What is your view on literacy, the progression of the students and the goal of literacy education?

- What is your perspective on mother tongue-based teaching for emergent readers?

- Can you tell me something about the history and the development of the school/ and its initial literacy teaching? 


\section{Appendix E: Table 2: Participants}

\begin{tabular}{|c|c|c|c|c|c|}
\hline $\begin{array}{l}\text { Pseudonym, } \\
\text { employment }\end{array}$ & $\begin{array}{l}\text { Sex } \\
\text { F/M } \\
\end{array}$ & School type & $\begin{array}{l}\text { Educational background } \\
\text { before LESLLA }\end{array}$ & Previously worked as or with & $\begin{array}{l}\text { Time in } \\
\text { LESLLA }\end{array}$ \\
\hline $\begin{array}{l}\text { Agnes } \\
\text { SFI teacher }\end{array}$ & $\mathrm{F}$ & Municipality & $\begin{array}{l}\text { Recreation instructor degree, } \\
\text { Junior school teaching } \\
\text { degree, course in Swedish as } \\
\text { a second language }\end{array}$ & $\begin{array}{l}\text { A recreation instructor, a teacher } \\
\text { of Swedish \& social studies in } \\
\text { junior school }\end{array}$ & $\begin{array}{l}5-10 \\
\text { years }\end{array}$ \\
\hline $\begin{array}{l}\text { Amela } \\
\text { SFI teacher } \\
\text { (previously } \\
\text { MT teacher) } \\
\end{array}$ & $\mathrm{F}$ & $\begin{array}{l}\text { Independent } \\
\text { folk high } \\
\text { school }\end{array}$ & $\begin{array}{l}\text { Upper secondary school } \\
\text { teaching degree }\end{array}$ & $\begin{array}{l}\text { A teacher in secondary school, a } \\
\text { mother tongue teacher in primary } \\
\text { school, in a bookbinder's }\end{array}$ & $\begin{array}{l}5-10 \\
\text { years }\end{array}$ \\
\hline $\begin{array}{l}\text { Ann-Sofie } \\
\text { SFI teacher }\end{array}$ & $\mathrm{F}$ & $\begin{array}{l}\text { Independent } \\
\text { folk high } \\
\text { school }\end{array}$ & $\begin{array}{l}\text { Teaching degree and course } \\
\text { in teaching Swedish as a } \\
\text { second language }\end{array}$ & $\begin{array}{l}\text { A teacher of students with } \\
\text { deficiencies in previous education } \\
\text { in intermediate school, a teacher } \\
\text { of social studies in adult } \\
\text { education }\end{array}$ & $\begin{array}{l}15> \\
\text { years. }\end{array}$ \\
\hline $\begin{array}{l}\text { Ellen } \\
\text { SFI teacher }\end{array}$ & $\mathrm{F}$ & Municipality & $\begin{array}{l}\text { Primary school teaching } \\
\text { degree }\end{array}$ & $\begin{array}{l}\text { An executive secretary, a teacher } \\
\text { in a primary school }\end{array}$ & Uncertain \\
\hline $\begin{array}{l}\text { Geedi } \\
\text { MT teacher }\end{array}$ & M & $\begin{array}{l}\text { Independent } \\
\text { folk high } \\
\text { school }\end{array}$ & $\begin{array}{l}\text { University courses in social } \\
\text { studies and a course in } \\
\text { interculturality }\end{array}$ & $\begin{array}{l}\text { A teacher in the mother tongue } \\
\text { subject in primary school }\end{array}$ & $\begin{array}{l}5-10 \\
\text { years }\end{array}$ \\
\hline $\begin{array}{l}\text { Ingrid } \\
\text { SFI teacher }\end{array}$ & $\mathrm{F}$ & $\begin{array}{l}\text { Tendering } \\
\text { company }\end{array}$ & $\begin{array}{l}\text { Primary school teaching } \\
\text { degree }\end{array}$ & A teacher in primary school & $\begin{array}{l}5-10 \\
\text { years }\end{array}$ \\
\hline $\begin{array}{l}\text { Jill } \\
\text { SFI teacher }\end{array}$ & $\mathrm{F}$ & Municipality & $\begin{array}{l}\text { Primary school teaching } \\
\text { degree }\end{array}$ & $\begin{array}{l}\text { A teacher in primary school and } \\
\text { an SFI teacher in other study } \\
\text { tracks }\end{array}$ & $\begin{array}{l}5-10 \\
\text { years }\end{array}$ \\
\hline $\begin{array}{l}\text { Karolina } \\
\text { SFI teacher }\end{array}$ & $\mathrm{F}$ & $\begin{array}{l}\text { Independent } \\
\text { folk high } \\
\text { school }\end{array}$ & $\begin{array}{l}\text { Degree in teaching Swedish } \\
\text { in the compulsory school** }\end{array}$ & A teacher in primary school & $<5$ years \\
\hline $\begin{array}{l}\text { Leonora } \\
\text { SFI teacher }\end{array}$ & $\mathrm{F}$ & $\begin{array}{l}\text { Tendering } \\
\text { company }\end{array}$ & $\begin{array}{l}\text { Teaching degree in } \\
\text { compulsory school }\end{array}$ & $\begin{array}{l}\text { A teacher in the compulsory } \\
\text { school }\end{array}$ & $\begin{array}{l}10-15 \\
\text { years }\end{array}$ \\
\hline $\begin{array}{l}\text { Louise } \\
\text { SFI teacher }\end{array}$ & $\mathrm{F}$ & Municipality & $\begin{array}{l}\text { Primary school teaching } \\
\text { degree }\end{array}$ & A teacher in primary school & $\begin{array}{l}10-15 \\
\text { years }\end{array}$ \\
\hline $\begin{array}{l}\text { Milly } \\
\text { SFI teacher }\end{array}$ & $\mathrm{F}$ & $\begin{array}{l}\text { Tendering } \\
\text { company }\end{array}$ & $\begin{array}{l}\text { Primary school teaching } \\
\text { degree }\end{array}$ & A teacher in primary school & $\begin{array}{l}15> \\
\text { years }\end{array}$ \\
\hline $\begin{array}{l}\text { Mohamed } \\
\text { MT teacher }\end{array}$ & $\mathrm{M}$ & $\begin{array}{l}\text { Independent } \\
\text { folk high } \\
\text { school }\end{array}$ & $\begin{array}{l}\text { Degree in interpretating } \\
\text { studies }\end{array}$ & $\begin{array}{l}\text { Different fields, e.g. as teacher } \\
\text { assistant in primary school, as an } \\
\text { interpreter }\end{array}$ & $<5$ years \\
\hline $\begin{array}{l}\text { Omaima } \\
\text { MT teacher }\end{array}$ & $\mathrm{F}$ & $\begin{array}{l}\text { Independent } \\
\text { folk high } \\
\text { school }\end{array}$ & $\begin{array}{l}\text { Primary school teaching } \\
\text { degree }\end{array}$ & $\begin{array}{l}\text { A teacher of English as a foreign } \\
\text { language in primary school }\end{array}$ & $\begin{array}{l}10-15 \\
\text { years }\end{array}$ \\
\hline $\begin{array}{l}\text { Omed } \\
\text { SFI teacher }\end{array}$ & $\mathrm{M}$ & Municipality & Degree in English literature & $\begin{array}{l}\text { A teacher of English, a teacher } \\
\text { assistant in SFI }\end{array}$ & $\begin{array}{l}10-15 \\
\text { years }\end{array}$ \\
\hline $\begin{array}{l}\text { Petronella } \\
\text { SFI teacher }\end{array}$ & $\mathrm{F}$ & Municipality & $\begin{array}{l}\text { Upper secondary school } \\
\text { teaching degree in Swedish } \\
\text { \& Swedish as a second } \\
\text { language }\end{array}$ & $\begin{array}{l}\text { Children and athletics, a personal } \\
\text { trainer, an SFI teacher in other } \\
\text { study tracks }\end{array}$ & $<5$ years \\
\hline $\begin{array}{l}\text { Rebecka } \\
\text { SFI teacher }\end{array}$ & $\mathrm{F}$ & Municipality & $\begin{array}{l}\text { Upper secondary school } \\
\text { teaching degree in French \& } \\
\text { Swedish, courses in Swedish } \\
\text { as a second language }\end{array}$ & $\begin{array}{l}\text { An upper secondary school } \\
\text { teacher }\end{array}$ & $<5$ years \\
\hline $\begin{array}{l}\text { Roya } \\
\text { MT teacher }\end{array}$ & $\mathrm{F}$ & $\begin{array}{l}\text { Independent } \\
\text { folk high } \\
\text { school }\end{array}$ & $\begin{array}{l}\text { Maths \& science teaching } \\
\text { degree for primary school }\end{array}$ & $\begin{array}{l}\text { An intern as a child minder, a } \\
\text { teacher of newly arrived } \\
\text { immigrants in primary school, a } \\
\text { language instructor in preschool }\end{array}$ & $\begin{array}{l}5-10 \\
\text { years }\end{array}$ \\
\hline $\begin{array}{l}\text { Sazan } \\
\text { SFI teacher }\end{array}$ & $\mathrm{F}$ & $\begin{array}{l}\text { Tendering } \\
\text { company }\end{array}$ & Master's degree in chemistry & $\begin{array}{l}\text { As a researcher \& teacher at } \\
\text { university, a sewing teacher in an } \\
\text { integration project }\end{array}$ & $\begin{array}{l}10-15 \\
\text { years }\end{array}$ \\
\hline $\begin{array}{l}\text { Simone } \\
\text { SFI teacher }\end{array}$ & $\mathrm{F}$ & Municipality & $\begin{array}{l}\text { Preschool teaching degree, a } \\
\text { special teaching degree }\end{array}$ & $\begin{array}{l}\text { A teacher in preschool \& primary } \\
\text { school }\end{array}$ & $\begin{array}{l}5-10 \\
\text { years }\end{array}$ \\
\hline
\end{tabular}




\section{Papers}

The papers associated with this thesis have been removed for copyright reasons. For more details about these see:

http://urn.kb.se/resolve?urn=urn:nbn:se:liu:diva-147356 


\section{LINKÖPING STUDIES IN BEHAVIOURAL SCIENCE}

181. FREJD, PETER. Modes of Mathematical Modelling. An Analysis of how modelling is used and interpreted in and out of school settings. 2014. ISBN: 978-91-7519-414-1

182. AMAN, ROBERT. Impossible Interculturality? Education and the Colonial Difference in a Multicultural World. 2014. ISBN: 978-91-7519-348-9

183. NYLANDER, ERIK. Skolning i jazz. Värde, selektion och studiekarriär vid folkhögskolornas musiklinjer. 2014. ISBN: 978-91-7519-347-2

184. GRADIN FRANZÈN, ANNA. Disciplining freedom: Treatment dilemmas and subjectivity at a detention home for young men. 2014. ISBN: 978-917519-344-1

185. ENGSTRÖM, ANNIKA. Lärande samspel för effektivitet. En studie av arbetsgrupper i ett mindre industriföretag. 2014. ISBN:978-91-7519-345-8

186. ELWÉR, ÅSA. Early Predictors of Reading Comprehension Difficulties. 2014. ISBN: 978-91-7519-281-9

187. LARSON, NICLAS. Matematikämnet och stadiebytet mellan grundskolan och gymnasieskolan. En enkät- och klassrumsstudie. 2014. ISBN: 978-917519-196-6

188. LY, HOA. Use of a Smartphone Application in the Treatment of Depression - The New Wave of Digital Tools for Psychological Treatment. 2015. ISBN: 978-91-7519-136-2

189. HANSSON, PER-OLOF. New ways of learning. Participatory action research and Kenyan runners' appropriation of smartphones to improve their daily lives and participation in m-learning. 2015. ISBN: 978-91-7519-124-9

190. BOLLDÈN, KARIN. Online teaching practices. Sociomaterial matters in higher education settings. 2015. ISBN: 978-91-7519-123-2

191. MALMQUIST, ANNA. Pride and Prejudice. Lesbian families in contemporary Sweden. 2015. ISBN: 978-91-7519-087-7

192. AVBY, GUNILLA. Evidence in Practice. On Knowledge Use and Learning in Social Work. 2015. ISBN: 978-91-74519-088-4

193. FORSBERG, CAMILLA. Students' Perspectives on Bullying. 2016. ISBN: 978-91-7685-874-5 
194. MUHRMAN, KAROLINA. Inget klöver utan matematik. En studie av matematik i yrkesutbildning och yrkesliv. 2016. ISBN: 978-91-7685-851-6

195. SKAGERLUND, KENNY. Magnitude Processing in Developmental Dyscalculia. A Heterogeneous learning disability with different cognitive profiles. 2016. ISBN: 978-91-7685-831-8

196. EKEBLAD, ANNIKA. A Randomized Trial of Interpersonal Psychotherapy and Cognitive Behavioral Therapy for Major Depressive Disorder Predictors of process and outcome. 2016. ISBN: 978-91-7685-803-5

197. MÅNSSON, KRISTOFFER N.T. Restructuring the Socially Anxious Brain. Using magnetic resonance imaging to advance our understanding of effective cognitive behaviour therapy for social anxiety disorder. 2016. ISBN: 978-91-7685-688-8

198. SILFVERNAGEL, KRISTIN. Individually tailored internet-based cognitive behavioural therapy for adolescents, young adults and older adults with anxiety. 2017. ISBN: 978-91-7685-566-9

199. ELOFSSON, JESSICA. Children's early mathematics learning and development. Number game interventions and number line estimations. 2017. ISBN: 978-91-7685-517-1

200. ÅHLFELDT, EMANUEL. Hållbart utvecklingsarbete i vård och omsorg. Ett institutionellt perspektiv på projekt i en professionell och byråkratisk kontext. 2017. ISBN: 978-91-7685-445-7

201. VERNMARK, KRISTOFER. Therapeutic alliance and different treatment formats when delivering internet-based CBT for depression. 2017. ISBN: 978-91-7685-436-5

202. FRANKL, MY. Psychotherapy for Substance Use Disorder - the importance of affects. 2017. ISBN: 978-91-7685-429-7

203. ABDULLA, AFRAH. Readiness or resistance? - Newly arrived adult migrants' experiences, meaning making, and learning in Sweden. 2017. ISBN: 978-91-7685-428-0

204. OLSSON, LINDA. “Count on me!”. Mathematical development, Developmental dyscalculia and computer-based intervention. 2018. ISBN: 978-91-7685-409-9 